\title{
Covid-19 Sürecinde Bilgi Açı̆̆ı: Beşiktaş ve Esenyurt İlçeleri Üzerine Bir
} Araştırma

Mihrali KÖSELIÖÖREN ${ }^{1}$

Cihan ÇAKIR ${ }^{2}$ Muhsin Samet OKUR ${ }^{3}$

\section{$\ddot{O} z$}

Gündelik hayatta bireylerin eylemlerinin belirli bir hedefe yönelik olmasının temelinde yer alan bilgi olgusu, endüstri devrimiyle birlikte bilgi kaynaklarını arttırmıştır. $\mathrm{Bu}$ durum ekonomik, toplumsal, eğitimsel ve bilimsel alanlarda köklü değişimlere neden olmuştur. Özellikle bilginin teknolojiyle buluşması sonucunda ortaya çıkan bilgi teknolojileri toplumun tüm kesimlerini eşit derecede bilgilendirmeyi amaçlamaktadır. Ancak hedef kitlenin ve toplumun sahip olduğu sosyo-ekonomik özellikler ve tercihler nedeniyle bilgi, toplumun farklı katmanlarına eşit şekilde yayılmayarak bilgi açığına neden olmaktadır. Bu çalışmada da akıllı telefon ve HES aplikasyonunun nasıl icra edildiği bu aplikasyonla ilgili kişilerin Covid-19 pandemisine yönelik bilgi düzeylerinin ne seviyede olduğu ve sosyal sınıf bağlamında bilgi açığının olup olmadığı ortaya konulmaya çalışılmıştır. Bunun sonucunda araştırma kapsamında incelenen Beşiktaş ilçesindeki katılımcıların Esenyurt ilçesindekilere göre daha iyi eğitim ve ekonomi düzeyene sahip olup akıllı telefonlar konusunda da daha bilgili olduğu görülmüştür. Ayrıca Beşiktaş ilçesindeki katılımcıların Esenyurt ilçesindeki katılımcılara göre HES uygulamasını daha etkili kullandığı saptanmıştır. Bu bağlamda Beşiktaş ilçesindeki katılımcıların Covid-19 pandemisi noktasında farkındalık düzeyleri Esenyurt ilçesindekilere göre daha yüksek olmaktadır.

Anahtar Sözcükler: Bilgi Açı̆̆ı, Sosyal Sınıf, Covid-19, Medya, Mobil Medya

\footnotetext{
1 Muş Alparslan Üniversitesi iletişim Fakültesi Gazetecilik Araştırma Görevlisi, m.koselioren@alparslan.edu.tr, Orcid ID: 0000-0001-7796-5634.

2 Doktora Öğrencisi, Selçuk Üniversitesi, Sosyal Bilimler Enstitüsü, Gazetecilik Anabilim Dalı, cihancakir001@gmail.com, Orcid ID: 0000-0002-4100-365X.

3 Bilim Uzman1, m.sametokur@gmail.com, Orcid ID: 0000-0001-5971-3863.

Bu makaleye atıf için: Köseliören, M., Çakır, C., \& Okur, M. S. (2021). Covid-19 Sürecinde Bilgi Açığı: Beşiktaş ve Esenyurt İlçeleri Üzerine Bir Araştırma. Aksaray İletişim Dergisi, 3(2), 201-233. doi:10.47771/aid.925187
} 


\section{Knowledge Gap In Covid-19 Process: A Study On Beşiktaş And Esenyurt Districts}

\section{Abstract}

The phenomenon of knowledge, which is the basis of the actions of individuals in everyday life towards a specific goal, has increased the sources of information with the industrial revolution. This has led to radical changes in the economic, social, educational and scientific fields. In particular, the information technologies that arise as a result of the meeting of information with technology aim to inform all segments of society equally. However, due to the socio-economic characteristics and preferences of the target audience and society, information does not spread equally to different layers of society, causing a knowledge deficit. In this study, how smartphone and HES application is performed, the level of knowledge levels of the people related to this application regarding the Covid-19 pandemic and the information deficit in the context of social class were tried to be revealed. As a result, it was observed that the participants in Besiktas district examined within the scope of the research had a better level of education and economy than those in Esenyurt district and were also more knowledgeable about smartphones. In addition, participants in Besiktas district were found to use HES more effectively than participants in Esenyurt district. In this context, the awareness levels of the participants in Besiktas district at the point of Covid-19 pandemic were higher than those in Esenyurt district.

Key Words: Knowledge Gap, Social Class, Covid-19, Media, Mobile Media

\section{Giriş}

Bilginin teknolojiyle birleşmesi sonucunda toplumlar, tarımdan bilgi toplumuna evrilmiştir. $\mathrm{Bu}$ durum toplumların yapısını ve kullanılan iletişim teknolojilerini değiştirmiştir. Toplumun farklı katmanları arasında bilgi açığının oluşmasında bireylerin ve sınıfların sahip olduğu eğitim, ekonomi, sosyal ilişki yapısı, bilginin seçilmesi ve kabulü gibi unsurların yanı sıra yeni iletişim teknolojilerine erişim düzeyleri de etkili olmaktadır. Bu teknolojilerden biri de akıllı telefonlardır. Dünya'da ve Türkiye'de akıllı telefonlar aracılığıyla internet erişimi giderek $\operatorname{artmaktadır}^{4}$ (wearesocial.com, 2021: 191). Bu bağlamda modern gündelik hayatın içerisinde baskın hale gelen internet sayesinde en önemli iletişim aracı olan akıllı telefonlar bireyler tarafından farklı amaçlarla kullanılmaktadır. Bu durum toplumun farklı sınıfları ve bireyleri arasında bilginin farklılaşmasına ve gediklerin oluşmasına neden olmaktadır.

\footnotetext{
${ }^{4}$ Dünya'da ve Türkiye'de akıllı telefonlar aracılığıyla internet erişimi giderek artmaktadır. Bu bağlamda Dünyada akıllı telefonlara bağlanarak internet kullanım oranlarına bakıldığında bu oranın \%102,4 olduğu saptanmıştır. Ayrıca Türkiye'de ise bu oranın \% 90,8 oranında olduğu görülmüştür (https://wearesocial.com/digital-2021)
} 
Özellikle akıllı telefon içerisindeki aplikasyonlar bireylerin ihtiyacına göre kullanılarak sınıfsal bir farklılaşmayı da ortaya koymaktadır. Bu durum Covid-19 pandemisi nedeniyle birçok insanın doğru bilgi alabilmek için en çok sağlıkla ilgili mobil aplikasyonları indirmesiyle görülmektedir (Becker ve ark., 2014: 1).

Sağlık uygulamalarının kullanılabilirliğindeki ve erişilebilirliğindeki bu artış, akıllı telefon sahiplerinin hangi sağlık uygulamalarını indirdiklerini ve bu uygulamaları nasıl kullandıkları konusunu önemli kılmaktadır. Bu anlamda mobil sağlık uygulamaları, kullanıcıların sağlık ve sağlıklı yaşam konusundaki bilgi düzeylerini farklılaştırmaktadır (Krebs ve Duncan, 2015: 2). Bireyler, mobil uygulamalar yoluyla sağlık alanında bilgi edinirken bu bilgileri nasıl anladıkları ve bu bilgileri doğru kullanıp kullanmadıkları önem kazanmaktadır. Bu durum bireylerin, sınıfsal konumlarına bağlı olarak değişmektedir. Bu bağlamda, sağlık konusunda toplumdaki bilgi açığı artmakta ve eşitsizlik ortaya çıkmaktadır (Sorensen, 2018: 89). Böylelikle toplumsal düzlemde yaşanan eşitsizlikler sadece eğitim, ekonomi ve politik yapılarda değil sağlık gibi alanlarda da eşitsizlikleri getirmektedir (Stormacq ve ark., 2018: 1).

Dünya genelinde mobil sağlık uygulamalarının kullanım oranları Covid-19 pandemisiyle birlikte artmaktadır (Statista, 2021). Türkiye'de ise pandemi sürecinin başlamasıyla birlikte, Hayat Eve Sığar (HES) Mobil Uygulaması sayesinde bireylerin Covid-19 pandemisine yönelik bilgilendirilmesi, yönlendirilmesi ve riskleri en az seviyeye indirmek ve yayılmasını önlemek amaçlanmıştır. HES uygulamasına benzer şekilde dünyada birtakım ülkelerde virüse karşı kontrol mekanizmaları oluşturmuştur. Bunlar arasında Avustralya'daki "COVIDSafe", Belçika'da Coronalert, Finlandiya'da Koronavilkku, İngiltere'de NHS COVID-19, Almanya'da Corona-Warn-App ${ }^{5}$ gibi uygulamalar yer almaktadır (wikipedia.org, 2021). Ayrıca Türkiye Cumhuriyeti Sağlık Bakanlığı'nın yayınladığı verilere göre HES uygulamasının 13.12.2020 tarihine kadar 40 milyon indirme sağladığı görülmüştür. (twitter.com/_hayatevesigar, 2021). Öte yandan ülkelere göre akıllı telefon kullanan nüfusun devlet destekli Covid-19 temas takip uygulamalarının indirilme oranları da ${ }^{6}$ değişmektedir (www.statista.com, 2021). Bu uygulamanın yanında pandemi sürecinde bireyler hem geleneksel medya hem de mobil medya gibi mecralar üzerinden de bilgilenmektedir. $\mathrm{Bu}$ bilgilenme sürecinin bireyler tarafından ne derece doğru algılanıp algılanmadığı önem arz

\footnotetext{
${ }^{5}$ COVIDSafe uygulaması 4.milyondan fazla, Coronalert uygulaması 1.7 milyondan fazla, Koronavilkku uygulaması 2,5 milyondan fazla, NHS COVID-19 uygulaması 10 milyondan fazla ve Corona-Warn-App ise 14,5 milyondan fazla kişi tarafından indirildiği saptanmıştır (wikipedia.org, 2021)

${ }^{6}$ Ülkelere göre akıllı telefon kullanan nüfusun devlet destekli Covid-19 temas takip uygulamalarının indirilme oranları değişmektedir. Bu bağlamda \%21 ile Avusturalya ve \% 17 ile Türkiye nüfusa göre temas takip uygulamalarını en çok indiren ülkelerdir (www.statista.com, 2021).
} 
etmektedir. Bu anlamda kişilerin sınıfsal konumlarının, eğitim ve sosyoekonomik düzeyleri gibi fırsat eşitsizliği yaratacak durumlarının pandemiyle ilgili konularda toplumda bir bilgi açığı durumu yaratıp yaratmadığı konusu bu çalışmanın amacını oluşturmaktadır. Bu amaç doğrultusunda çalışmada, bilgi açığı ve sınıf kavramları teorik olarak incelenmiş ve akıllı telefon, HES uygulaması üzerinden verilen sağlık ve pandemi süreciyle ilgili bilgilerin anlamlandırılmasında kişilerin sınıfsal konumlarının toplumda bir bilgi açı̆̆ı yaratıp yaratmadığı saha araştırmasıyla ölçülmeye çalışılmıştır.

\section{Kavramsal Olarak Bilgi Açı̆̆ı Modeli}

Bilgi toplumsal bir etkinlik (Bozkurt, 2004: 9) olarak insanların yaşamlarını sürdürebilmesinde, gereksinimlerini karşılamasında, sosyal etkinliklerinde önemli bir rol oynamaktadır (Uçak, 200: 143). Bu anlamda bilgi, özne olan insan ile nesne olan her türlü varlık arasında yaşanan zihinsel bir süreç olmaktadır (Aydın, 2010: 20). Çünkü bilgi, kavramların ortaya çıktığı, tanımlandığı, uygulandığı ve dönüştüğü birikimli bir alan olarak görülmektedir (Foucault, 2011: 212). Bu birikimin görünür olduğu yer ise bireylerin birbirleriyle bir iktidar mücadelesi içerisinde bulunduğu gündelik hayattır. Bu durumda bilgi öznel bir boyutun yanı sıra toplumsal bir süreç olmaktadır (Cohen, 1986: 577).

Bilginin teknolojik ilerlemeyle birleşmesiyle tarım toplumundan sanayi toplumuna geçilmiştir (Toffler, 2008: 16). Ancak 1950 ve 1960'l1 y1llarda bilgi teknolojilerinin giderek artan bir şekilde kullanılması sonucunda bilgi toplumu ortaya çıkmıştır (Aktan ve Tunç, 1998: 134). Bilgiye dayalı bu toplum, hızlı değişim gösteren ve kısa sürede gelişen bir yapıda olmaktadır. Teknolojiyle birlikte gelişen bilgi toplumunda, bilgi teknolojileri, bilgi sektörleri, bilgi üretimi gibi konular öne çıkmaktadır (Samadova, 2021: 72). Ayrıca bilgi toplumunda insan faktörü önem kazanmakta, eğitimin sürekliliği ve iletişim teknolojileri gibi gelişmeler görülmektedir (Uçkun ve ark., 2005: 24). Bilgi toplumu içerisinde gerçekleşen teknolojik gelişmeler sonucunda cep telefonları gibi modern iletişim araçları ve mecraları gündelik hayatta daha baskın hale gelmeye başlamıştır. Böylelikle SES (sosyo ekonomik statüsü) yüksek olan toplumlardaki bireyler SES'i düşük toplumlara ve bireylere göre bu araçlarda daha fazla vakti geçirmektedir (Dijk, 2018: 12). Bu yüzden bilgi toplumu kolektif biçimde kendini sürdürme gerekliliği ile birlikte baştan beri uyum içinde olmayan bireysel istekleri de içinde barındırmaktadır. $\mathrm{Bu}$ anlamda toplumsallaşmayla zorunlu bir bağ içinde olan bilgi süreçleri (Habermas, 1997: 105) sosyal sistem içindeki tüm katmanlara eşit şekilde yayılmamaktadır. Bunun sonucunda farklı toplumsal katmanlarda yaşayan bireyler arasında bilgi açıklığ görülmektedir (Viswanath ve Finnegan, 2006: 188). Böylelikle bilgi toplumu içerisindeki 
bireyler arasında görülen bilgi açıklığının anlaşılabilmesi (Bektaş Şeker, 2005: 55) için kuramsal bir tartışmanın yapılması gerekmektedir.

Bilgi açığı modeli ilk kez 1970’li yıllarda P. J. Tichenor, G. A. Donohue ve C. N. Olien tarafından yazılan “Kitle Medyasının Akışı ve Bilgideki Farklı Büyüme” adlı çalışmayla sistematize edilmiştir (Tichenor, ve ark., 1970: 159-161). Bilgi açı̆̆1 modelinin temelinde, enformasyon aktarımı yapan araçların hedef kitleyi eşit bilgilendirme konusundaki başarısızlığı bulunmaktadır (Bonfadelli, 2002: 67). Bu bağlamda modele göre, KİA ile aktarılan bilginin giderek artması sonucunda bilgiye daha fazla erişme olanağı olan toplumsal katmanların diğerlerine oranla daha fazla bilgiye sahip olduğu görülmüştür (Mutlu, 2012: 50). Ayrıca toplumsal bir sistemde iyi eğitim görmüş, yüksek sosya ekonomik statüdeki kişilerin, daha az eğitim görmüş ve alt statüdeki kişilere göre enformasyonu daha iyi benimseyebileceği de iddia edilmektedir. Böylelikle toplumun farklı katmanları arasında yaşanan bilgiye yönelik farklılaşma çoğunlukla enformasyon gediği veya bilgi gediği olarak adlandırılmaktadır (McQuail ve Windahl, 2010: 153-155). Bilgi gediğinin oluşmasında bireylerin kişisel özellikleri, bilgi edinme becerileri, eğitim ve sosyoekonomik durumları gibi toplumsal katmanlardaki konumu etkileyen değişkenler önemli rol oynamaktadır (Holbrook, 2002: 438). Çünkü bilgi açığı modeli toplumun temelindeki sosyal yapının bir sonucu olan bilgi akışının homojen olmadığını savunmaktadır (Bonfadelli, 2002: 67).

Bazı durumlarda, "ayrıcalıklı” ve "az ayrıcalıklı” kesimler arasındaki bilgi açığının her zaman

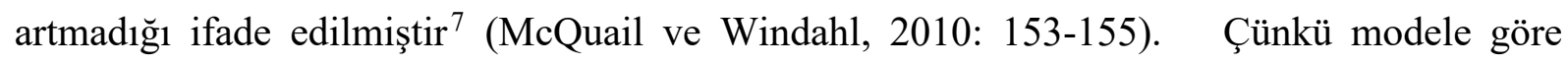
toplumdaki çatışma seviyesi arttığında, bilginin çok yüksek oranda topluma nüfuz ettiğinde, bazı konuların medyada çok fazla tekrar edildiğinde, hedef kitlenin konuya olan ilgi seviyesi ve medya bağımlılığı düzeyi arttığında ve bireylerin toplum bağları güçlü olduğu durumlarda toplumun farklı kesimleri arasındaki bilgi açığının azalma eğilimi gösterdiği görülmektedir (Yanık ve Güz, 2017: 4-5). Bu durum “tavan etkisi” olarak ifade edilmekte ve bireylerin içinde bulunduğu belirli durumlarda enformasyon kapasitesi ve SES'i yüksek olan kesimler ile enformasyon kapasitesi ve SES'i düşük olan kesimler arasındaki bilgi düzeyleri azalmakta veya eşitlenmektedir (Ettema ve Kline, 1977: 183). Donohue, Phillip ve Clarice gibi araştırmacılar ise tavan etkisi düşüncesine karşı çıkıp bilgi açığının hiçbir zaman kapanmayacağını savunmaktadır. Çünkü bu araştırmacılar çoğulcu yapıya sahip olan

\footnotetext{
$7 \mathrm{Bu}$ duruma örnek olarak İsveç’te trafiğin sol yandan sağ yana değişmesinden önceki enformasyon kampanyasını örnek alarak düşünebiliriz. Başlangıçta daha sonra kaybolan belirli bir enformasyon gediği veya bilgi gediği vardır (McQuail ve Windahl, 2010: 153-155).
} 
toplumların homojen toplumlardan daha fazla sosyal kurumlara sahip olduğunu belirtmektedir. Böylelikle bireylerin içinde bulunduğu toplumsal sistem farklılaştığı için bilgi açığının da kapanmayacağı görüşü savunulmaktadır (Donohue, ve ark., 1975: 8). Bilgi gediği modeline yönelik çeşitli tartışmaların olması, bilgi gediğinin oluşmasındaki tek unsurunun KİA olmadığını göstermektedir. Bu anlamda tartışmaların netleştirilebilmesi için bilgi açı̆̆ı modelini oluşturan unsurların tartışılması gerekli kılınmaktadır.

\section{Bilgi Açı̆̆ı Modelinin Oluşmasındaki Unsurlar}

Toplumsallaşma bireyin içinde yer aldığ 1 sınıfın normlarını, değerlerini, tutumlarını edinmesini sağlamaktadır (Çoştu, 2009: 119). Toplumsallaşmanın oluşmasında ise aile, eğitim, arkadaş çevresi, ekonomi, siyaset ve medya gibi kurumlar etkili olmaktadır. Ancak her toplumun sınıfsal yapısı farklı olduğundan, bu yapının belirlediği işlevlerde farklı olmaktadır. Bundan ötürü, farklı sınıflardaki bireylerde toplumsallaşma sürecinde belirgin farklılıklar oluşmaktadır (Aziz, 1982: 23). Bu anlamda toplumdaki farklı sınıflar arasında ekonomi, eğitim, kültür ve sağlık gibi alanlarda belirli farklılıklar meydana gelmektedir. $\mathrm{Bu}$ durumda toplumun farklı sınıfları arasında meydana gelen bilgi açığının saptanabilmesi için çeşitli değişkenler kullanmıştır (Tichenor ve ark., 1970: 161).

\subsection{Eğitim Yapısı}

Bireylerin içinde yaşadığı topluma sağlıklı bir şekilde uyum sağlaması için belirli davranış örüntüleriyle donanmış olması gerekmektedir (Özkan, 2006: 35). Bu anlamda bireylerin ve toplumların gelişmesinde önemli bir rol oynayan eğitim kurumu, kişinin gelişmesine yardım eden ve onu esas alan, gerekli bilgi, beceri ve davranışlar elde etmesini sağlayan bir süreç olmaktadır (Tezcan, 1985: 4). Ancak eğitimin gerçekleştirdiği bu evrensel işlevler toplumsal ve sınıfsal koşullara göre değişmektedir (Yıldız ve Karakaş, 2019: 272). Eğitim kurumu eşitsiz bir dünya yaratmaktadır (Russell, 1999: 57). Çünkü eğitimin temelinde yer alan okul kurumu egemenlerin istediği alt sınıfları yaratmaktadır. Bu yüzden egemen konumunda yer alan bireylerin eğitim ve sosyal yaşantı firsatları daha fazla olmaktadır (Illıch, 2006: 64-65). Böylelikle sosyoekonomik statüleri yüksek olan bireyler gelişmiş eğitim ve gelir imkânlarına ve daha fazla referans kaynaklarına sahip olmaktadır (Severin ve Tankard, 2014: 249-252). $\mathrm{Bu}$ durumda yüksek eğitime sahip olan bireylerin belirli konulara olan ilgisi toplumun alt katmanlarındakilere göre daha fazla olmaktadır (Bonfadelli, 2002: 66). Bu anlamda eğitime sahip olan bireyler bilim ve teknoloji gibi karmaşık konuları; düşük eğitim gruplarına göre daha iyi okuma ve anlama becerilerine sahip olarak bilgi açığını neden olmaktadır (Tichenor ve ark., 1970: 162). 


\section{2. Sosyal İlişki Yapısı}

Toplum, birbirini destekleyen ve etkileşim içerisinde olan işlevsel sistemler barındırmakta, bütünün parçaları ve işlevleriyle anlamlı hale gelmektedir (Poe ve Durkheim, 2008: 79). Çünkü toplumlar kendilerine ait sınırları ve yapıları oluşturmaktadır. Bu durumda çoğulcu bir yapıya sahip olan toplumların mesleki statüleri, istihdam imkânları, devlet hizmetleri, iletişim araçları ve diğer sosyal kurumları homojen toplum yapılarına göre daha çeşitli olmaktadır. (Ritzer, 2011: 197; Donohue, ve ark., 1975: 8). Bu durum daha geniş bir günlük faaliyet alanını, daha fazla sayıda referans grubuyla veya kişilerarası teması göstermektedir. Böylelikle bireyler arasında gerçekleşen sosyal ilişki sayesinde bilgi alışverişi artarak toplumun diğer katmanlarına göre bilgi seviyesi yükselip bilgi açıklığına neden olmaktadır (Tichenor ve ark., 1970: 62).

\section{3. Bilginin Seçilmesi ve Kabulü}

Bireyler etraflarında olan olaylara karşı gelişen ilgi ve merakı giderebilmek için daha fazla bilgiye ihtiyaç duyarak, daha yüksek oranda ve daha kararlı biçimde medya kullanımını gerçekleştirmektedir (Terkan, 2005: 108-109). Bireyler, sabit faaliyet alanları ve istikrarlı sosyal ağlarıyla ilgili bilgi alabilmek için medyaya yönelmekte ve daha önce elde ettikleri bilgiyi geliştirmede daha etkin konumda olmaktadır. Ancak bireylerin içinde bulunduğu toplumsal katmana göre yöneldiği haber türü farklılaşmaktadır (Genova ve Greenberg, 1979: 82). Böylelikle farklı katmanlarda bulunan bireylerin motivasyonları, ilgileri ve haberi kullanma becerileri değişmektedir. Bu yüzden sosyoekonomik yapısı düşük olan bireyler çeşitli haber türlerine ulaşsalar bile haberi kullanma açısından yüksek sosyoekonomik katmandaki bireyler kadar etkin olamamaktadır (Speight, 1999: 140). SES’i yüksek olan bireylerin bilim ve kamu işleriyle ilgili haberlere daha fazla ilgi gösterirken; daha düşük katmandaki bireyler ise bu öğrenimden yoksun olmaktadır. Böylelikle toplumun farklı katmanlarında yaşayan bireyler arasında bilgi gedikleri meydana gelmektedir (Tichenor ve ark., 1970: 162).

\subsection{Yeni İletişim Teknolojilerine Erişim Düzeyleri}

Yeni iletişim teknolojileri, enformasyonun belli amaçlar çerçevesinde iletilmesini, işlenmesini, saklanmasını ve bu işlevleri yerine getirecek yöntem, aygıt ve sistemlerin gerekli yazılımlarıyla birlikte geliştirilmesinin bilgi ve deneyimini ifade etmektedir (Göker, 2001: 34-35). Bu anlamda bilgi toplumuyla birlikte yaygınlaşan internet, çeşitli türdeki enformasyonun işlenmesine olanak sağlayan bilgisayarlar ve görüntü kaydedebilen cep telefonları gibi teknolojiler sayesinde toplumsal iletişim süreci yapısal dönüşüme uğratmıştır 
(Geray ve Aydoğan, 2010: 310). Bu dönüşümün sonucunda bireyler aktif bir duruma gelirken, metin multimedya biçimine evirilmiş, teknolojik araçlar küçülerek kolayca taşınabilir hale gelmiş ve depolama yapısı soyutlaşarak sınırsızlaşma gibi özellikler ortaya çıkmıştır (Aydoğan ve Kırık, 2012: 60). Böylelikle iletişim teknolojilerindeki ilerleme sonucunda yerleşik normlarda köklü değişiklikler meydana gelerek sosyal, ekonomik, siyasal ve eğitimsel sorunların çözüldüğü bir alan haline gelmiştir (Ayhan, 2018: 10). Ancak yeni iletişim araçlarının benimsenmesinden, erişilmesinden ve kullanım becerisinden kaynaklanan iletilen ve alınan bilgi miktarının toplumun farklı katmanları arasında farklılaştığı görülmektedir (Katzman, 1974: 49-50). Bu anlamda teknolojik gelişmeler bireyler arasında ya da toplumda hem ekonomik hem de sosyolojik ve kültürel temelli bilgi gediklerine neden olmaktadır (Çelik, 2019: 69).

Toplumların gelişiminin temel aktörlerinden biri olan bilgi bireylerin gereksinimlerini sürdürebilmesinden, iktidar mücadelelerine kadar uzanmaktadır. Ancak toplumların ve bireylerin sahip oldukları dinamikler yüzünden bilginin kullanım pratikleri toplumun farklı katmanları arasında çeşitlilik göstererek bilgi gediklerinin oluşmasına neden olmaktadır. $\mathrm{Bu}$ gediklerinden oluşmasında eğitimden bilginin kabulüne, yeni iletişim teknolojilerinden toplumsal yapıya kadar birçok unsur yer almaktadır. Ancak bu unsurların ve bilgi açığının anlamlandırılabilmesi için kişilerin bulunduğu sosyal sınıfların özelliklerinin de tartışılması gerekmektedir.

\section{Bilgi Açığını Görünür Kılan Bir Alan Olarak Sosyal Sınıf Kavramı}

Günümüzde bireyler internet ve mobil araçlar sayesinde medyayı daha kolay ve hızlı bir şekilde takip etmektedir. Bu durum konu özelinde toplumdaki bilgi açığını etkilemektedir. Toplum içerisinde yaşayan insanların sınıfsal konumu kişilerin bu araçları nasıl ve ne derece anlamlı kullandığını etkilemektedir. Bu durum özellikle toplumun genelini ilgilendiren sağlık gibi konularda görülmektedir. Bu anlamda, sınıf yaklaşımı, bireylerin kişisel özelliklerinden ziyade toplumdaki konumunun önemini vurgulamakta ve bunu yaparak bireylerin farklı alanlardaki davranış kalıplarını ortaya koymaktadır. Böylece, sınıfsal konum, sağlık, eğitim, iş, gelir, yoksulluk ve sosyal hareketlilik gibi daha birçok farklı alanda eşitsizliklere yol açmaktadır. Bu anlamda, bu alanlar üzerine yapılan çalışmalarda sınıf kavramını açıklamak önem kazanmaktadır.

Sınıf kavramı 14. ve 16. yüzyıllarda 'yurttaşları, sahip oldukları servete göre ayıran çeşitli kategorileri anlatmak' için kullanılmaktadır (Beneton, 1991: 11-12). Sınıf kavramının sosyolojik ve siyasal ya da hiyerarşik anlam taşıması İngiltere' deki modern toplum yapılarının 
ortaya çıkmasıyla başlamıştır (Garnsey ve Saller, 2014: 23). Modern toplumların tanımlanmasının bir parçası olan sosyal sınıf kavramı, önceden var olan ve eşitsizlikle temellenen güç, statü veya ekonomik kaynak ilişkileriyle bireyler üzerinde kalıcı sonuçlar bırakan deneyimler olmaktadır (Bottero, 2005: 3). Bu deneyimler bireylerin içinde bulunduğu sosyal sınıfa göre nesnel kaynaklar, sosyal roller tarafindan yönetilen saygı, ahlaki değerler, eğitim, sanat, ekonomi, prestij ve kültür gibi imgesel pratikleri farklılaştırmaktadır. Çünkü bir sınıfın üyesi olmak genellikle görünür göstergeler, imgeler ve sosyal rollerle tanımlanmaktadır (Saunders, 2001:28; Cohen ve ark., 2017:1531).

Sınıfsal farklılıkların temelinde eşitsiz toplumsal ilişkiler bulunmaktadır (Grusky 2008: 30). $\mathrm{Bu}$ anlamda sosyal sınıf, hem hiyerarşik bir güç ve kontrol sistemindeki göreceli konumu olarak ekonomik temelli alt yapılarla (Diemer ve ark., 2013: 79) hem de eğitim, kültür ve tarih gibi üst yapı unsurlarla ilgili olmaktadır (Bumpus ve ark., 2019: 2). Böylelikle sosyal sınıfın yarattığı alt ve üst yapı unsurları kişinin yaşadığı toplumsal düzendeki konumunu ve sosyal dayanışma duygusunu tanımlayan kültürel boyutları (Booth, 2020: 5) ve hatta insanların nasıl düşündükleri, hissettikleri ve nasıl davrandıkları üzerinde yaygın psikolojik etkileri de belirlemektedir (Yu ve Blader, 2020: 332).

Sosyal sınıfların bugünkü popülaritesinin oluşmasında etkin rol oynayan alt yapı temelli ekonomik anlayışta, Marksist yaklaşımın sınıf anlayışı ön plana çıkmaktadır. Buna göre, sosyal sınıflar, üretim ilişkileri doğrultusunda tanımlanmaktadır. Marksist düşüncede sınıf terimi, üretim araçlarıyla ortak bir ilişkisi olan insanları ifade etmektedir (Giddens, 2012:344). Marksist teorisyenlere göre modern toplumların temelinde çıkarları uğruna birbirleriyle rekabet halinde olan burjuvazi ve proletarya olarak iki ana sınıf bulunmaktadır. Bu sinıflardan proletarya ile üretim araçlarının sahipleri arasında bir ayrım yapılmakta, böylelikle ilki ikincisi tarafından kâr amacıyla sömürülmektedir. O halde Marksist teorisyenler için sınıf ilişkileri tahakküm ve sömürü ile karakterize edilmektedir (Day ve ark., 2020: 12). Bu tahakküm ve sömürünün temelinde bireylerin sahip olduğu ekonomik karakteristik yapılar etkili olmaktadır. Bu yüzden gelir seviyesi, gelir istikrarı ve gelir gelişim beklentileri gibi yapılar sınıfsal fark değiştikçe artmaktadır. Çünkü bireyler finansal kaynak durumlarına göre gündelik hayatlarını devam ettirebilmek için farklı ekonomik çabalar göstermektedir (Lahtinen ve ark., 2017:392).

Sosyal sınıf kavramı ekonomik anlamının dışında birçok farklı alanda kendini göstermektedir. Çünkü sınıfsal farklılıklarda tek belirleyici ekonomi olmamaktadır. Bu görüş Weber ve onun ardılı olan düşünürler tarafından savunulmaktadır. Bu anlamda Weberyan sosyal sınıf analizi, 
Marksist düşüncenin aksine ekonomiyi tek belirleyici unsur olarak görmemektedir. $\mathrm{Bu}$ anlamda Weberyan anlayış sağlık, eğitim, kültür, gelir, meslek gibi kriterleri dikkate alarak sosyal sınıf anlayışını değiştirmektedir (Weber, 2019: 269-270). Bu durumda sosyal sınıf toplumsal hayatın farklı alanlarında kendini göstererek etkisini genişletmektedir. Bu alanlardan biri olan sağlık kurumu da sosyal, psikososyal, ekonomik ve kültürel güçler tarafından şekillendirilmektedir. Böylece sosyal sınıfsal bağlamda düşük sosyoekonomik pozisyondaki insanlar, daha yüksek pozisyonlardaki bireylere göre daha sağlıksız bir yapıda olmaktadır. Böylelikle sınıfsal konumlar diğer unsurlarda olduğu gibi sağlık alanında da eşitsizliklere neden olmaktadır (Lahelma ve ark., 2010: 61-62). Ortaya çıkan bu eşitsizlik aslında bireylerin sağlık alanında sahip olduğu ayrıcalıkları da göstermektedir. Böylelikle yoksul bir toplumda, diğerlerinin yanı sıra kötü sağlık sorunları oldukça doğrudan yoksulluğa yorumlanabilmektedir. Ancak, toplumsal olarak, sağlık eşitsizlikleri yoksullarla ve yoksul olmayanlarla sınırlı değildir ve tüm toplumu etkilemektedir. Bu duruma sınıfsal eşitsizlikler yol açmaktadır (Marmot, 2004: 22).

Bireylerin ve nüfusların sahip olduğu SES'ler hem fiziksel hem de psikolojik anlamda olumsuz sağlık durumlarında etkin rol oynamaktadır (Compton ve Shim, 2015: 4). Çünkü SES sağlık açısından değerlendirildiğinde bireylerin sahip olduğu sosyal sınıflarının en altında olduğu algısı en üstte olmaktan daha fazla psikolojik stres ve depresyon üretmektedir (Li ve ark., 2018: 295). Bu anlamda alt sınıflardakilerde çeşitli psikolojik hastalıkların fazlalığı, yalnızca strese daha fazla maruz kalmaya değil, aynı zamanda sınıfsal konuma da bağlanabilmektedir (Angermeyer ve Klusmann, 1987:11). Sağlıkta yaşanan sosyal eşitsizlik toplumda sağlıkla ilgili konularda bilgi açığı yaratmaktadır. Bu açığın büyümesinde kişilerin eğitim ve gelir düzeylerinin yanında medya takibi ya da konuyla ilgili motivasyonları, bilimsel anlamda sağlıkla ilgili haberlere verilen önemin az olması gibi unsurlar önemli bir etkendir (Ettema ve ark., 1983: 517). Ayrıca medyaya ve mesajlara dikkat, bilginin yayılmasından gelen bilgilerin hatırlanması ve saklanması, daha düşük SES gruplarına kıyasla daha yüksek SES grupları tarafından daha iyi anlaşılmaktadır. Bu durum sağlık özelinde, kişilerin sınırlı sağlık okuryazarlığının hastalık yönetiminde etkin rol oynadığını göstermektedir (Nielsen-Bohlman ve ark., 2004: 7). Kişilerin sağlık durumlarına olan bilgileri takip etmeleri ve anlamaları onların eğitim seviyeleriyle doğru orantılıdır. Bu anlamda sosyal sınıf bağlamında eğitimin önemi artmaktadır.

Eğitim hem toplumda eşitliği sağlamanın aracı hem de eşitsizliklerin yeniden üretimine merkezi bir şekilde dâhil edilmiş olarak gösterilmektedir. Sosyal sınıf eşitsizliklerini 
hafifletmenin alanlarından biri olarak görülen eğitim aslında bu eşitsizlikleri daha da belirgin hale getirmektedir (Reay, 2006: 291). Böylelikle toplumun üst sınıflarında olan kişiler için iyi bir eğitim almak ve daha yüksek eğitim düzeyine ulaşmak alt sınıflardaki kişilere göre daha görünür olmaktadır. Bu durum eğitim alanında eşitsizlikler yaratmaktadır (Stephens ve ark., 2015: 2). Çünkü alt sinıflar daha kötü ekonomik şartlar ve işsizlik gibi sorunlarla karşılaşmaktadır. Bu durumda eğitimin sosyal sınıfın en önemli ön koşulu olması, eğitimin işsizlikteki sosyal sınıf tabakalaşmasını açıklamaktadır. Bu anlamda, eğitim, işsizlik ve düşük gelire karşı en iyi koruma olarak görülmektedir (Lahtinen ve ark., 2018: 306).

Dünya çapında eğitim hala sosyal alanda üretim ve statükoyu güçlendirmektedir. $\mathrm{Bu}$, ailelerin okulla ilişkilerine getirebilecekleri kültürel olduğu kadar, maddi kaynakların düzeyiyle ilgili bir sorun olarak da görülmektedir. Bu anlamda ailenin ekonomik ve sınıfsal durumu kişilerin eğitimle ilgili faaliyetlerini doğrudan etkilemektedir (Reay, 2010: 398). Eğitim sadece okul içerisinde olan bir durumu ifade etmemektedir. Toplumun farklı sınıflarında, kişinin bağlı bulunduğu sosyal çevre ve ailesinin eğitimi de önem kazanmaktadır. $\mathrm{Bu}$ anlamda ebeveynlerin eğitim seviyesi, kişisel kaynakları ve problem çözme yetenekleri sağlıklı bilişsel bir gelişim için gereklidir. Yani, ebeveynlerinin eğitim ve bilinç düzeyleri, kişinin eğitim ve akademik başarısı için önemli olmaktadır (Gonzalez ve ark., 2020: 52). Sosyal koşullardan bağımsız olarak, küçük çocukların eğitim deneyimleri, ailelerinin sosyal sınıf geçmişine bağlı olarak farklılık göstermektedir. Orta ve üst sınıf ebeveynler, çocuklarının eğitimine yatırım yapmak için genişletilmiş kaynaklara sahip olmanın yanı sıra, daha düşük sosyoekonomik geçmişe sahip ebeveynlere kıyasla, okul dışında da bireysel olarak çocuklarını eğitmektedir (Yamamoto, 2013: 166). Spesifik olarak, düşük statülü ailelerin çocukları genellikle daha düşük eğitim seviyelerine ve ardından düşük statülü mesleklere ulaşırken, yüksek statülü ailelerin çocukları tipik olarak daha yüksek statü mesleklerine yol açan daha yüksek eğitim seviyelerine ulaşmaktadırlar. Bu durum, sosyal sınıfın kişinin ileri eğitim alma kararını güçlü bir şekilde etkilediğini göstermektedir (Bumpus ve ark., 2019: 2).

Sonuç olarak sosyal sınıflar, kişilerin statüsünü ortaya koymakta, ekonomi, kültür, eğitim, sağlık ve psikoloji gibi birbirini etkileyen ve birbirinden etkilenen çok boyutlu bir olgu olmaktadır. Bu anlamda araştırma kapsamında sosyal sınıflar arasında yaşanan bilgi açığının Covid-19 pandemisinin yayılmasına yönelik etkisini ortaya koyabilmek için hem salgına yönelik genel bir çerçeve çizmek hem de bu sürecin toplumsal durumları nasıl etkilediğini ortaya koymak gerekmektedir. Bu yüzden sonraki bölümde Covid-19 pandemi sürecinin yarattığı toplumsal değişimler araştırma kapsamında tartışılmaktadır. 


\section{Covid-19 Pandemi Sürecinde Toplumsal Değişim}

Tarih boyunca salgın hastalıklar dünya genelinde krizlere neden olurken, uluslararası ölçekte çözüm gerektiren ve kaynak tahsisi isteyen bir alan olarak ortaya çıkmıştır. Günümüzde yaşanan Covid- 19 pandemisi de (Ulun, 2020: 91) Aralık 2019 tarihinden itibaren ortaya çıkıp küresel bir salgına neden olarak geçmişteki örnekleriyle benzerlik göstermiştir. Ancak Covid-19 sadece bireylerin sağlıklarına etki eden bir pandemi olmamaktadır. Bu anlamda bu etki sadece hastalığa yakalananlarla sınırlı da değildir. Bu durumda etki boyutu birçok alanda kendisini göstermektedir. Bu bağlamda Covid-19 pandemisinin sosyal, siyasal, ekonomik ve psikolojik etkileri de bulunmaktadır (Bozkurt ve ark., 2020: 304). Bilgi açığının pandemiyle olan ilişkisini anlamlandırabilmek amacıyla bu ilişkilerin incelenmesi gerekmektedir.

\subsection{Ekonomik Etkiler}

Salgın hastalıklar, ekonomik düzlemde kritik kırılma noktalarının oluşmasına neden olmaktadır. Covid-19 pandemisi de sağlığın yanında ekonomik, toplumsal ve psikolojik krizlere de sebebiyet vermiş ve bu özelliğiyle çok yönlü bir pandemi haline dönüşmüştür (Temir, 2020: 51). Özellikle pandemi sürecinde, devletler üretim, yatırım ve ticaret faaliyetlerini sınırlandırmıştır (Botta ve ark., 2020). Bu durum özellikle gelişmekte olan ülkeleri olumsuz yönde etkilemiştir. Ekonominin bu olumsuz seyrinden güçlü ekonomiler de zarar görmüştür. Birdenbire artan işsizlik oranları, gelirlerdeki azalış ve maliyetlerdeki artış küresel bir krize sebebiyet vermiştir (Nar, 2020: 368).

$\mathrm{Bu}$ süreçte özellikle harcama alışkanlıklarının değişmesi, ihtiyaçlara ilişkin önceliklerin dönüşmesi durumunun ve çalışma şartlarındaki dönüşümler de dikkat çekicidir (Ulun, 2020: 93). İşsizlik oranları, kaygı ve belirsizlikle beraber hemen her ülkede yükselmektedir. Gelişmekte olan ülkelerde yoksulluk ve beslenme yetersizliği artmaktadır (Chaudry, 2020: 27). Covid-19'a bağlı olarak çoğunlukla düşük gelir ve beslenme statüsüne sahip olan kesimlerin daha da yoksulluğa sürüklenebileceği tahmin edilmektedir (Gedik, 2020: 668). Pandemi sürecini yaşayan ülkelerin ekonomik kırılganlıklarından dolayı yoksullar, fırsatlardan dişlananlar ve dijital olarak ötekileştirilenler zarar görmektedir (Duhalde, 2020: 42-43). Bu durumda ortaya çıkan eşitsizlik ve gelir dağılımındaki adaletsizliğe yönelik itirazlar toplumsal hareketler ve verilerle ortaya çıkmaktadır. Bu yüzden salgının ekonomik etkilerinin yanı sıra toplumsal etkileri de araştırma kapsamında tartışılmaktadır.

\subsection{Toplumsal Etkiler}

Pandemiler, bireyi ve toplumu etkileyen sosyal bir olgu olarak da karşımıza çıkmaktadır (Karataş, 2020:6). Çünkü toplumsal yapıyı oluşturan kurumlardan biri de sağlık olmaktadır. 
$\mathrm{Bu}$ nedenle sağlık bireysel bir durum olmanın çok ötesinde toplumsaldır. $\mathrm{Bu}$ açıdan bakıldığında pandemiler, yalnız sağlık sorunu olarak değil, aynı zamanda insanların sosyal, politik, ekonomik, kültürel alanlarını da etkileyen toplumsal bir sorun olarak görülmektedir (Selamzade vd. 2020: 539).

Toplumların bilinçaltlarını etkileyen Covid-19 pandemisi (Menchú Tum, 2020: 141) bireylerde korku ve kaygı düzeyini arttırarak toplumların davranış kalıplarını ve tutumlarını etkilemiştir (Taştan ve ark. 2020:6). Çünkü korku ve kaygının topluma yayılmasıyla bireylerarası dayanışma zayıflayarak toplumda güvensizlik ortaya çıkmıştır (Karataş, 2020:6). $\mathrm{Bu}$, gündelik hayatın farklı noktalarında da kendini göstermiştir. Özellikle toplumsal yaşamdaki sosyal ilişkilerin belli bir süre askıya alınarak ilişkilerin dijital platformlar aracılığıyla devam ettirilmesine neden olmuştur (Ahmadi, 2020: 67). Bu durum bireylerin evlerinde daha çok zaman geçirmesine neden olurken hareketsiz bir yaşama karşı bireylerin alternatifler üretme pratiğini de geliştirmiştir (Afacan ve Avcı 2020: 12). Böylelikle kişiler eğitim, çalışma, alışveriş ve sosyal faaliyetlerini uzaktan yani online yapmaya başlamışlardır.

\subsection{Eğitimsel Etkiler}

Covid-19 salgınının yayılmasını önlemek amacıyla alınan tedbirler eğitim alanında da bazı olumsuz etkilere neden olmuştur (Akat ve Karataş, 2020: 2). Bu olumsuzlukların aş1lması amacıyla online eğitim ön plana çıkmıştır (Afacan ve Avcı, 2020: 11). Bu bağlamda gerçekleşen online eğitim, internet aracılığıyla öğrencilerin ve öğretmenlerin uzakta olmalarına rağmen eş zamanlı ya da ayrı zamanlı olarak iletişim kurdukları ve bilgileri aktardığı bir eğitim sistemi olmaktadır (Kırmızıgül, 2020: 286).

$\mathrm{Bu}$ kapsamda eğitim salgın sürecinde okullardan sosyal ağlara taşınmıştır. Ancak, çoğu ülkede, bilgisayar, internet ve diğer çevrimiçi platformların eksikliği, bazı ülkelerde erişim firsatı sunulmaması gibi nedenlerden dolayı pek çok eğitim bilimci zihinsel ve bilişsel gelişim açısından okul ortamının daha verimli olduğunu savunmaktadır (Karataş, 2020: 62). Böylelikle Covid-19 pandemisinden sonra gerçekleşen online eğitim sonucunda ortaya çıkan dijital bölünmeyle birlikte dijital teknolojilere ulaşanlar ile ulaşamayanlar arasındaki farklılık daha belirgin hale getirmiştir. Bu anlamda, dijital bölünme toplumsal kesimler arasındaki bilgi gediğinin büyümesine de neden olmuştur (Bozkurt 2020: 125).

Covid-19 pandemisiyle beraber, toplumların eğitim, sağlık, ekonomi gibi alanları etkilenmektedir. $\mathrm{Bu}$ anlamda, pandemi toplumların farklı alanlarda sürekli hale gelmiş davranışlarında değişime gitmelerine neden olmaktadır. Bu değişimin bir sonucu olarak, kişiler sağlıklarına daha çok dikkat etmeye başlamakta, sağlık ve tıp konuları hakkında daha 
çok bilgi edinmeye çalışmaktadır. Bunu yaparken en çok akıllı telefonlarına başvurmaktadırlar. Akıllı telefonlar hem her yerde kişilerin hemen bakıp kullanabileceği hem de içerisindeki uygulamalarla kişilere sağlık konusunda farklı alternatif bilgi edinme yolları sundukları araçlar olduğundan önem kazanmaktadır. Ancak kişilerin akıllı telefon kullanma durumları ve uygulamalardaki sağlı bilgilerini doğru bir şekilde anlama durumları farklılık göstermektedir. Bu farklılık temelde toplumsal sınıf farklılıklarından kaynaklanmaktadır. Toplumun daha üst sınıflarında olan kişiler teknolojiyi daha etkin bir şekilde kullanarak sağlık konusunda bilgiye daha rahat ulaşıp bu bilgileri daha iyi analiz edebilirken toplumun alt kesimindeki kişiler tam tersi bir durum gösterebilmektedir. Bu durum ise toplumda sağlık konusunda ve konu özelinde Covid-19 pandemisinde bir bilgi açığına neden olmaktadır. Bu anlamda çalışma toplumun farklı kesimlerindeki kişilerin hem teknoloji kullanımı noktasında hem sağlık ve tıp konularında hem de Covid-19 pandemisi özelinde nasıl farklılıklar gösterdiğini ortaya çıkarmaya çalışmaktadır.

\section{Yöntem}

Araştırma kapsamında iletişim alanının temel modellerinden biri olan bilgi açığı modeli esas alınarak bir iletişim aracı olan akıllı telefon ve HES uygulamasının kullanım durumundan kaynaklanarak Covid-19 pandemisine yönelik toplumun farklı kesimlerinde bilgi açığının oluşup olmadığı tespit edilmiştir. Bu bağlamda uygulama kısmında ise akıllı telefon ve HES uygulamasının nasıl kullanıldığı bu uygulamayla ilgili kişilerin Covid-19 pandemisine yönelik bilgi düzeylerinin ne seviyede olduğu ve bireylerin bilgi düzeylerinin sosyal sinıf bağlamında nasıl değişiklik gösterdiği ortaya konulmaya çalışılmıştır. $\mathrm{Bu}$ araştırmanın gerçekleşebilmesi için Esenyurt ve Beşiktaş ilçeleri seçilmiştir. Araştırmadaki ilçelerin seçilmesinde TUIKK $^{8}$ verilerinden yola çıkarak bilgi açığının temelinde yer alan eğitim unsurunun her iki ilçede de farklılaşması etkili olmuştur. $\mathrm{Bu}$ doğrultuda toplumun farklı kesimleri arasındaki bilgi açığını ölçmek amacıyla niceliksel alan araştırması kapsamında anket tekniği kullanılmıştır.

Araştırmaya katılan Esenyurt ve Beşiktaş ilçelerinde yaşayanların akıllı telefon, HES uygulaması ve Covid-19 pandemisine yönelik bilgi açıklığını ölçmek amacıyla 35 sorudan oluşan anket formu kullanılmıştır. Anket formu katılımcılar tarafindan anlaşılabilecek şekilde konu ile ilgili yapılmış daha önceki araştırmalardan yararlanılarak düzenlenmiştir. Soru formu

\footnotetext{
${ }^{8}$ Araştırma kapsamında incelenen Esenyurt ilçesindeki okuma yazma bilmeyen sayısı 14.831 olurken, Beşiktaş’ta ise bu durum 948 kişi olmaktadır. Ayrıca Esenyurt ilçesi İstanbul'daki ilçeler arasında en fazla okuma yazma bilmeyen orana sahip olan ilçe konumundadır (tuik.gov.tr).
} 
3 ana bölümden oluşmaktadır. İlk bölümde demografik özelliklere, ikinci bölümde akıllı telefonlara ve üçüncü bölümde ise HES ve Covid-19 pandemisine yönelik sorular yer almaktadır. Araştırmada kullanılan bu ölçek Tülay Şeker tarafından yazılan "Yeni Bir Illetişim Teknolojisi Olarak Internet ve Bilgi Açı̆̆ ” isimli doktora tezinden alınmıştır (Şeker Bektaş, 2004). İnternete yönelik bilgi açığını ölçmek için kullanılan bu anket bir iletişim aracı olan cep telefonu bağlamında HES ve Covid-19 salgınına yönelik bilgi açığını ölçmek amacıyla uyarlanmıştır. Bilgi açığının ortaya çıkartılabilmesi için iki bağımsız grup arasındaki niceliksel sürekli verilerin karşılaştırılabilmesi için t-testi kullanılmıştır.

\section{Bulgular}

$\mathrm{Bu}$ bölümde, araştırma probleminin çözümü için, araştırmaya katılan öğrencilerin ölçekler yoluyla toplanan verilerin analizi sonucunda elde edilen bulgular yer almaktadir. Elde edilen bulgulara dayalı olarak tablo analizleri ve yorumlarına yer verilmiştir.

\section{Katılımcıların Sosyo Demografik Özellikleri}

\begin{tabular}{|c|c|c|c|c|c|c|c|c|}
\hline & & \multicolumn{2}{|c|}{ Esenyurt } & \multicolumn{2}{|c|}{ Beşiktaş } & \multicolumn{2}{|c|}{ Toplam } & \multirow{2}{*}{$\mathbf{p}$} \\
\hline & & $\mathrm{n}$ & $\%$ & $\mathrm{n}$ & $\%$ & $\mathrm{n}$ & $\%$ & \\
\hline \multirow{4}{*}{ Eğitim } & İlkokul & 99 & $\% 49,5$ & 1 & $\% 0,5$ & 100 & $\% 25,0$ & \multirow{4}{*}{$\begin{array}{l}X^{2}=137,911 \\
p=0,000\end{array}$} \\
\hline & Lise & 72 & $\% 36,0$ & 102 & $\% 51,0$ & 174 & $\% 43,5$ & \\
\hline & Üniversite & 26 & $\% 13,0$ & 87 & $\% 43,5$ & 113 & $\% 28,2$ & \\
\hline & Lisansüstü & 3 & $\% 1,5$ & 10 & $\% 5,0$ & 13 & $\% 3,2$ & \\
\hline \multirow{4}{*}{ Meslek } & Memur & 11 & $\% 5,5$ & 33 & $\% 16,5$ & 44 & $\% 11,0$ & \multirow{4}{*}{$\begin{array}{l}X^{2}=20,240 \\
p=0,000\end{array}$} \\
\hline & \begin{tabular}{|l|} 
Ev Hanımı \\
\end{tabular} & 22 & $\% 11,0$ & 17 & $\% 8,5$ & 39 & $\% 9,8$ & \\
\hline & İşçi & 73 & $\% 36,5$ & 43 & $\% 21,5$ & 116 & $\% 29,0$ & \\
\hline & Diğer & 94 & $\% 47,0$ & 107 & $\% 53,5$ & 201 & $\% 50,2$ & \\
\hline \multirow{4}{*}{ Gelir } & 2000 TL'den az & 30 & $\% 15,0$ & 21 & $\% 10,5$ & 51 & $\% 12,8$ & \multirow{4}{*}{$\begin{array}{l}X^{2}=11,866 \\
p=0,008\end{array}$} \\
\hline & $2000-3000 \mathrm{TL}$ & 80 & $\% 40,0$ & 56 & $\% 28,0$ & 136 & $\% 34,0$ & \\
\hline & $3000-4000 \mathrm{TL}$ & 67 & $\% 33,5$ & 84 & $\% 42,0$ & 151 & $\% 37,8$ & \\
\hline & $4000-6000 \mathrm{TL}$ & 23 & $\% 11,5$ & 39 & $\% 19,5$ & 62 & $\% 15,5$ & \\
\hline
\end{tabular}

Tablo 1. Katılımcıların Sosyo-Demografik Özelliklerinin Dağılımı

Eğitim ile katılımcıların yaşadıkları yer arasında anlamlı ilişki bulunmuştur $\left(\mathrm{X}^{2}=137,911\right.$; $\mathrm{p}=0,000<0.05)$. Bu durumda Esenyurt ilçesindeki katılımcıların yarısına yakınının yani 99'unun $(\% 49,5)$ ilkokul mezunu olduğu saptanmıştır. Beşiktaş’ta ise katılımcıların 102'si yani yarısından fazlasının $(\% 51,0)$ lise mezunu olduğu görülmüştür. Lise mezunlarının ardından katılımcıların 87'si $(\% 43,5)$ üniversite mezunu olduğu ortaya çıkmıştır.

Katılımcıların mesleki durumlarıyla nerede yaşadıkları arasında anlamlı ilişki bulunmuştur $\left(X^{2}=20,240 ; p=0,000<0.05\right)$. Bu bağlamda Esenyurt ilçesindeki katılımcıların yüksek orana sahip olan meslek gruplarından biri ise 73 kişi ile $(\% 36,5)$ işçiler olduğu görülürken Beşiktaş ilçesinde ise katılımcıların Esenyurt ilçesinden farklı olarak memur oranının yüksek olduğu saptanmıştır. 
Katılımcıların gelir dağılım ile nerede yaşadığı arasında anlamlı ilişki bulunmuştur

\begin{tabular}{|c|c|c|c|c|c|c|c|c|}
\hline \multirow{4}{*}{$\begin{array}{l}\text { Akıllı telefon kullanma } \\
\text { noktasında kendinizi ne kadar } \\
\text { yeterli görüyorsunuz? }\end{array}$} & 3 & 1 & $\% 0,5$ & 0 & $\% 0,0$ & 1 & $\% 0,2$ & \multirow{8}{*}{$\begin{array}{l}X^{2}=39,247 \\
p=0,000\end{array}$} \\
\hline & 4 & 18 & $\% 9,0$ & 5 & $\% 2,5$ & 23 & $\% 5,8$ & \\
\hline & 5 & 26 & $\% 13,0$ & 8 & $\% 4,0$ & 34 & $\% 8,5$ & \\
\hline & 6 & 14 & $\% 7,0$ & 37 & $\% 18,5$ & 51 & $\% 12,8$ & \\
\hline \multirow{4}{*}{$\begin{array}{l}* 1-10 \text { arasındaki ölçekte } \\
10 \text { (Çok İyi) } \\
1 \text { (Çok Kötü) }\end{array}$} & 7 & 34 & $\% 17,0$ & 18 & $\% 9,0$ & 52 & $\% 13,0$ & \\
\hline & 8 & 41 & $\% 20,5$ & 65 & $\% 32,5$ & 106 & $\% 26,5$ & \\
\hline & 9 & 39 & $\% 19,5$ & 35 & $\% 17,5$ & 74 & $\% 18,5$ & \\
\hline & 10 & 27 & $\% 13,5$ & 32 & $\% 16,0$ & 59 & $\% 14,8$ & \\
\hline \multirow{4}{*}{$\begin{array}{l}\text { Ne kadar zamandir akı1lı telefon } \\
\text { kullanıyorsunuz? }\end{array}$} & $1-3$ Y1l & 2 & $\% 1,0$ & 0 & $\% 0,0$ & 2 & $\% 0,5$ & \multirow{4}{*}{$\begin{array}{l}X^{2}=11,107 \\
p=0,011\end{array}$} \\
\hline & 4-6 Yil & 17 & $\% 8,5$ & 4 & $\% 2,0$ & 21 & $\% 5,2$ & \\
\hline & 7-10 Y11 & 95 & $\% 47,5$ & 96 & $\% 48,0$ & 191 & $\% 47,8$ & \\
\hline & 10 Y1l ve Üzeri & 86 & $\% 43,0$ & 100 & $\% 50,0$ & 186 & $\% 46,5$ & \\
\hline \multirow{2}{*}{$\begin{array}{l}\text { Akıllı telefonunuzu ne sıklıkla } \\
\text { kullanırsinız? }\end{array}$} & $\begin{array}{l}\text { Günde } 1 \text { Defadan } \\
\text { Fazla }\end{array}$ & 195 & $\% 97,5$ & 200 & $\% 100,0$ & 395 & $\% 98,8$ & \multirow{2}{*}{$\begin{array}{l}X^{2}=5,063 \\
p=0,030\end{array}$} \\
\hline & Haftada Bir Kez & 5 & $\% 2,5$ & 0 & $\% 0,0$ & 5 & $\% 1,2$ & \\
\hline
\end{tabular}

$\left(\mathrm{X}^{2}=11,866 ; \mathrm{p}=0,008<0.05\right) . \mathrm{Bu}$ kapsamda araştırma kapsamında Esenyurt ilçesindeki katılımcıların 80’i (\%40,0) 2000-3000 TL arasında gelire sahip olduğunu belirtirken Beşiktaş ilçesinde ise katılımcıların 84'ünün (\%42,0) 3000-4000 TL aralığında bir gelire sahip olduğu belirlenmiştir.

\section{Katılımcıların Akıllı Telefon Kullanımına İlișkin Özellikleri}

Tablo 2. Katılımcıların Akıllı Telefon Kullanımına İlişkin Özellikler

Araştırma kapsamında katılımcıların akıllı telefon kullanma yeterliği ile nerede yaşanıldığ arasında anlamlı ilişki olduğu görülmüştür $\left(X^{2}=39,247 ; p=0,000<0.05\right)$. Bu çerçevede Esenyurt'taki katılımcıların 41'inin (\%20,5) akıllı telefon kullanma yeterliği noktasında 1-10 aralığında belirtilen ölçekte 8 oranını belirtirken Beşiktaş ilçesindeki katılımcıların 65'inin (\%32,5) 1-10 arasındaki yeterlik ölçeğinde 8 oranını tercih ettikleri ortaya çıkmıştır.

Katılımcıların ne kadar zamandır akıllı telefon kullandığı ile nerede yaşadıkları arasında anlamlı ilişki görülmektedir $\left(\mathrm{X}^{2}=11,107 ; \mathrm{p}=0,011<0.05\right)$. Araştırma kapsamında Esenyurt ilçesindeki katılımcıların 95'inin (\%47,5) 7-10 yıl aralığında akıllı telefon kullandıklarını belirttikleri saptanmıştır. Araştırma kapsamında Beşiktaş ilçesindeki katılımcılar arasında 100'ünün $(\% 50,0)$ ne kadar zamandır akıllı telefon kullandıklarını ilişkin olarak 10 yıl üzeri süre belirttikleri bulgulanmıştır.

Katılımcıların akıllı telefonu ne sıklıkla kullandıkları ile nerede yaşanıldığı arasında da anlamlı ilişki görülmüştür $\left(X^{2}=5,063 ; p=0,030<0.05\right)$. Araştırma kapsamında Esenyurt ilçesindeki katılımcıların çok büyük bir kısmının 195 (\%97,5) günde 1 defadan fazla akıllı telefon kullandıkları ortaya çıkmıştır. Araştırma kapsamında Beşiktaş ilçesindeki 
katılımcıların tamamı ise $200(\% 100,0)$ günde 1 defadan fazla akı1lı telefon kullandığı saptanmıştır.

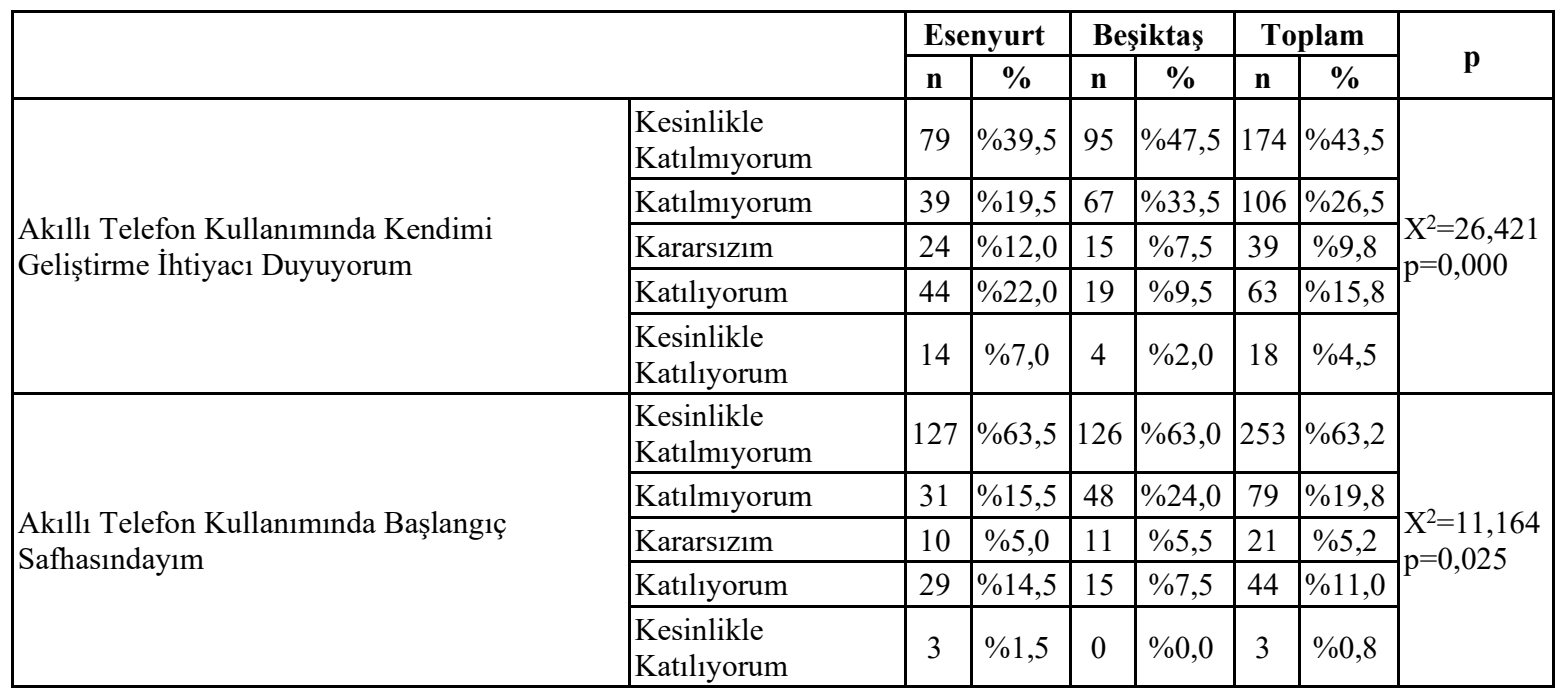

Tablo 3. Katılımciların Akıllı Telefon Kullanım Yetisi

Araştırma kapsamında akıllı telefon kullanım yetisi noktasında, katılımcılara yöneltilen 'akıllı telefon kullanımında kendimi geliştirme ihtiyacı duyuyorum' ifadesine ilişkin yanıtları ile nerede yaşadıkları arasında anlamlı ilişki olduğu görülmektedir $\left(X^{2}=26,421 ; p=0,000<0.05\right)$. $\mathrm{Bu}$ çerçevede Esenyurt ilçesindeki katılımcıların 44'ünün $(\% 22,0)$ katılıyorum cevabını verdikleri görülürken 39'unun $(\% 19,5)$ ise katılmıyorum cevabı verdiği ortaya çıkmıştır. Araştırma kapsamında Beşiktaş ilçesindeki katılımcıların 67'sinin $(\% 33,5)$ katılmıyorum yanıtını verdikleri, 19’unun ise $(\% 9,5)$ katılıyorum cevabına yöneldikleri görülmüştür.

Araştırma çerçevesinde akıllı telefon kullanım yetisi noktasında, katılımcılara yöneltilen 'akıllı telefon kullanımında başlangıç safhasındayım' ifadesine ilişkin yanıtlanı ile nerede yaşadıkları arasında anlamlı ilişki olduğu görülmektedir $\left(X^{2}=11,164 ; p=0,025<0.05\right) . \mathrm{Bu}$ bağlamda Esenyurt ve Beşiktaş ilçesindeki katılımcıların 'kesinlikle katılmıyorum' yanıtına verdikleri yanıtlar benzerlik göstermektedir. Ancak Esenyurttaki katılımcıların 29'unun $(\% 14,5)$ katılıyorum yanıtını verdiği saptanırken Beşiktaş’ta ise, 15'inin $(\% 7,5)$ ise katılıyorum yanıtını verdiği ortaya çıkmıştır. 


\begin{tabular}{|c|c|c|c|c|c|c|c|c|}
\hline & & \multicolumn{2}{|c|}{ Esenyurt } & \multicolumn{2}{|c|}{ Beşiktaş } & \multicolumn{2}{|c|}{ Toplam } & \multirow[b]{2}{*}{$\mathbf{p}$} \\
\hline & & $\mathrm{n}$ & $\%$ & $n$ & $\%$ & $\mathrm{n}$ & $\%$ & \\
\hline \multirow{4}{*}{$\begin{array}{l}\text { Akı1lı Telefon Çok Önemli Bir Teknolojidir } \\
\text { Ama Kullanmam }\end{array}$} & \begin{tabular}{|l} 
Kesinlikle \\
Katılmıorum
\end{tabular} & 164 & $\% 82,0$ & 167 & $\% 83,5$ & 331 & $\% 82,8$ & \multirow{4}{*}{$\begin{array}{l}X^{2}=10,524 \\
p=0,015\end{array}$} \\
\hline & \begin{tabular}{|l|} 
Katılmiyorum \\
\end{tabular} & 18 & $\% 9,0$ & 28 & $\% 14,0$ & 46 & $\% 11,5$ & \\
\hline & Kararsızım & 9 & $\% 4,5$ & 4 & $\% 2,0$ & 13 & $\% 3,2$ & \\
\hline & Katıliyorum & 9 & $\% 4,5$ & 1 & $\% 0,5$ & 10 & $\% 2,5$ & \\
\hline \multirow{5}{*}{$\begin{array}{l}\text { Akı1lı Telefon Kullanmadan Zaman } \\
\text { Geçirebilirim }\end{array}$} & \begin{tabular}{|l|} 
Kesinlikle \\
Katılmıyorum \\
\end{tabular} & 36 & $\% 18,0$ & 11 & $\% 5,5$ & 47 & $\% 11,8$ & \multirow{5}{*}{$\begin{array}{l}X^{2}=19,637 \\
p=0,001\end{array}$} \\
\hline & Katılmiyorum & 49 & $\% 24,5$ & 39 & $\% 19,5$ & 88 & $\% 22,0$ & \\
\hline & Kararsızım & 36 & $\% 18,0$ & 53 & $\% 26,5$ & 89 & $\% 22,2$ & \\
\hline & Kat1lyyorum & 56 & $\% 28,0$ & 71 & $\% 35,5$ & 127 & $\% 31,8$ & \\
\hline & $\begin{array}{l}\text { Kesinlikle } \\
\text { Katıllyorum }\end{array}$ & 23 & $\% 11,5$ & 26 & $\% 13,0$ & 49 & $\% 12,2$ & \\
\hline \multirow{5}{*}{$\begin{array}{l}\text { Aradığım Şeylere Akıllı Telefon Olmadan } \\
\text { Ulaşabilirim }\end{array}$} & \begin{tabular}{|l} 
Kesinlikle \\
Katılmıyorum
\end{tabular} & 91 & $\% 45,5$ & 12 & $\% 6,0$ & 103 & $\% 25,8$ & \multirow{5}{*}{$\begin{array}{l}X^{2}=82,494 \\
p=0,000\end{array}$} \\
\hline & Katılmiyorum & 8 & $\% 4,0$ & 17 & $\% 8,5$ & 25 & $\% 6,2$ & \\
\hline & Kararsızım & 29 & $\% 14,5$ & 57 & $\% 28,5$ & 86 & $\% 21,5$ & \\
\hline & Kat1lyyorum & 57 & $\% 28,5$ & 92 & $\% 46,0$ & 149 & $\% 37,2$ & \\
\hline & \begin{tabular}{|l} 
Kesinlikle \\
Katıllyorum
\end{tabular} & 15 & $\% 7,5$ & 22 & $\% 11,0$ & 37 & $\% 9,2$ & \\
\hline \multirow{4}{*}{ Akıllı Telefon Kullanımına Karşıyım } & \begin{tabular}{|l|} 
Kesinlikle \\
Katılmıorum \\
\end{tabular} & 165 & $\% 82,5$ & 171 & $\% 85,5$ & 336 & $\% 84,0$ & \multirow{4}{*}{$\begin{array}{l}X^{2}=24,507 \\
p=0,000\end{array}$} \\
\hline & Katılmiyorum & 10 & $\% 5,0$ & 26 & $\% 13,0$ & 36 & $\% 9,0$ & \\
\hline & Kararsızım & 9 & $\% 4,5$ & 1 & $\% 0,5$ & 10 & $\% 2,5$ & \\
\hline & Katıliyorum & 16 & $\% 8,0$ & 2 & $\% 1,0$ & 18 & $\% 4,5$ & \\
\hline
\end{tabular}

Tablo 4. Katılımcıların Akıllı Telefona İlişsin Tutumları

Araştırma kapsamında katılımcıların akıllı telefona ilişkin tutumları çerçevesinde 'akıllı telefon çok önemli bir teknolojidir ama kullanmam' ifadesine ilişkin yanıtları ile nerede yaşadıkları arasında anlamlı ilişki olduğu görülmektedir $\left(X^{2}=10,524 ; p=0,015<0.05\right) . \mathrm{Bu}$ çerçevede Esenyurt ve Beşiktaş ilçesindeki katılımcıların 'kesinlikle katılmıyorum' yanıtında benzerlik gösterdiği saptanmıştır. Ancak Eseyurttaki katılımcıların 'katılıyorum' yanıtı 9 kişiyle $(\% 4,5)$ sınırlı olurken Beşiktaş’ta ise 1 kişinin $(\% 0,5)$ sadece 'katılıyorum' yanıtını verdiği görülmüştür.

Araştırma kapsamında katılımcıların 'akıllı telefon kullanmadan zaman geçirebilirim' ifadesine ilişkin verdikleri yanıtlar ile nerede yaşanıldığı arasında anlamlı ilişsi olduğu görülmektedir $\left(X^{2}=19,637 ; p=0,001<0.05\right)$. Bu bağlamda Esenyurt ilçesinde katılımcıların 36'sının $(\% 18,0)$ ise kesinlikle katılmıyorum yanıtını verdiği bulgulanmıştır. Beşiktaş ilçesindeki katılımcılarda ise 11 'inin $(\% 5,5)$ ise kesinlikle katılmıyorum yanıtını verdikleri de saptanmıştır.

Araştırma kapsamında katılımcıların 'aradığım şeylere akıllı telefon olmadan ulaşabilirim' ifadesine verdikleri yanıtlar ile nerede yaşadıkları arasında anlamlı ilişki olduğu görülmektedir $\left(X^{2}=82,494 ; p=0,000<0.05\right)$. Bu çerçevede Esenyurt ilçesinde katılımcıların 
91'inin $(\% 45,5)$ kesinlikle katılmıyorum yanıtını verdikleri görülmüştür. Katılımcıların 57'sinin $(\% 28,5)$ ise katılıyorum yanıtını verdiği bulgulanmıştır. Araştırma çerçevesinde Beşiktaş ilçesinde ise katılımcıların 92'sinin $(\% 46,0)$ katılıyorum yanıtını verdikleri görülürken 12 'sinin $(\% 6,0)$ ise kesinlikle katılmıyorum yanıtını verdikleri saptanmıştır.

Katılımcıların 'akıllı telefon kullanımına karşıyım' ifadesine verdikleri yanıtlar ile nerede yaşadıkları arasında anlamlı ilişki olduğu görülmektedir $\left(X^{2}=24,507 ; p=0,000<0.05\right)$. Bu kapsamda Esenyurt ve Beşiktaş ilçesindeki katılımcıların 'kesinlikle katılmıyorum' yanıtı benzerlik gösterdiği bulgulanmıştır. Öte yandan Esenyurttaki katılımcıların 16 'sının $(\% 8,0)$ 'katıllyorum' yanıtını verdikleri görülürken Beşiktaş ise 2 kişinin $(\% 1,0)$ 'katılıyorum' yanıtını verdikleri bulgulanmıştır.

Katılımcıların Covid-19 ve Hayat Eve Sığar Uygulamasına Yönelik Bilgi Düzeyi, Tedavi Süreçleri ve Tutumları

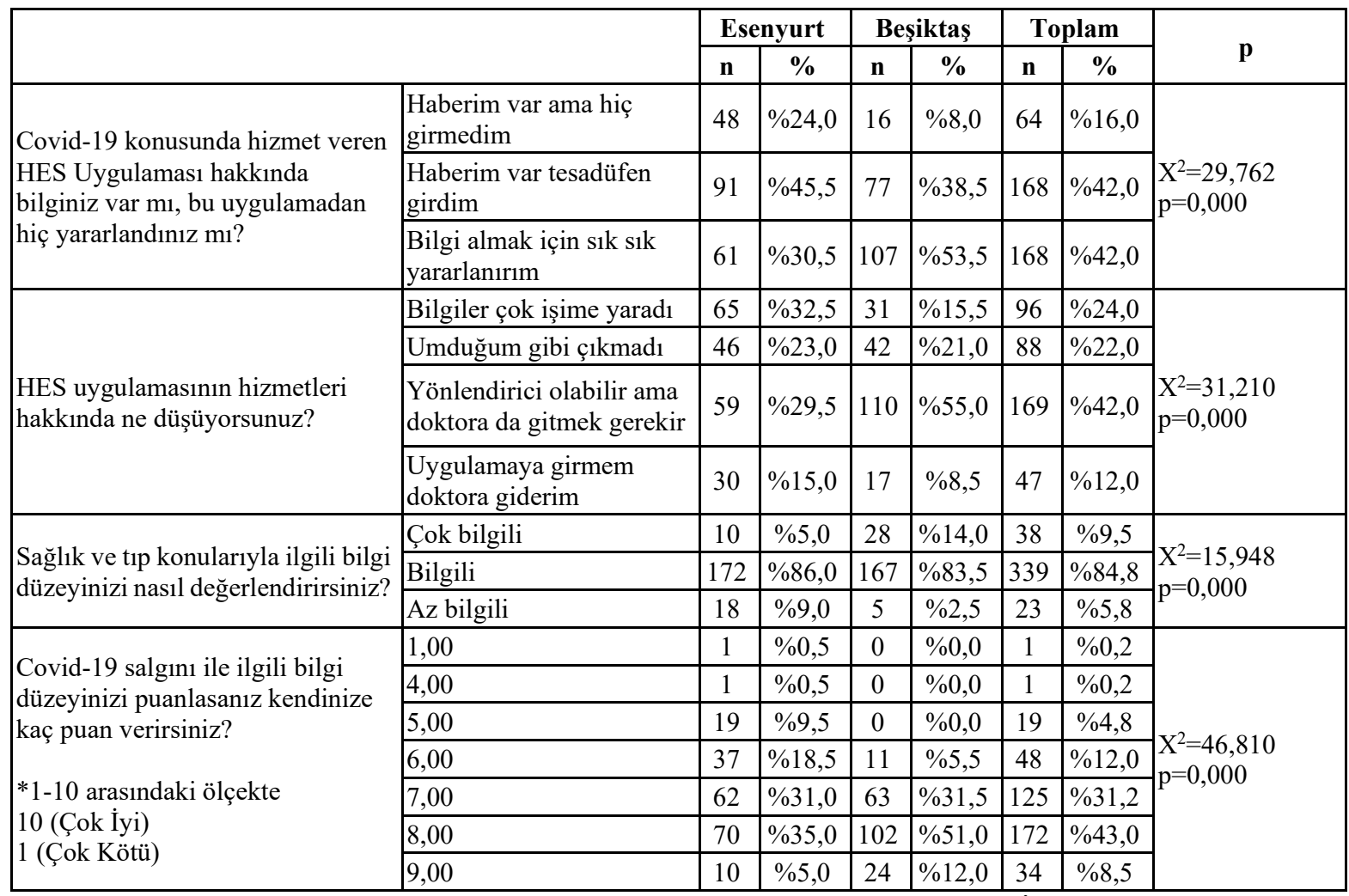

Tablo 5. Katılımcıların Covid-19 ve Hayat Eve Sığar Uygulamasına İlişkin Bilgi Düzeyi ve Tutumları

Araştırma kapsamında katılımcıların Hayat Eve Sığar (HES) uygulamasına ilişkin olarak, 'Covid-19 konusunda hizmet veren HES uygulaması hakkında bilginiz var mi, bu uygulamalardan hiç yararlandınız $m \imath$ ?' sorusuna ilişkin verdikleri yanıtlar ile nerede yaşadıkları arasında anlamlı ilişski olduğu görülmektedir $\left(X^{2}=29,762 ; p=0,000<0.05\right) . B u$ çerçevede Esenyurt ilçesindeki katılımcıların 48'inin $(\% 24,0)$ ise 'haberim var ama hiç 
girmedim' olarak yanıt verdiği bulgulanırken Beşiktaş ilçesinde ise katılımcıların 16'sının $(\% 8,0)$ 'haberim var ama hiç girmedim' yanıtını verdikleri de görülmüştür.

Araştırma kapsamında katılımcıların 'Covid-19 salgınını geçirdiniz mi?' sorusuna ilişkin verdikleri yanıtlar ile nerede yaşadıkları arasında anlamlı ilişki olduğu görülmektedir $\left(X^{2}=4,476 ; p=0,029<0.05\right)$. Bu çerçevede Esenyurt ilçesinde katılımcıların 14 'ünün $(\% 7,0)$ ise evet yanıtını verdikleri saptanırken Beşiktaş ilçesindeki katılımcıların 5'inin $(\% 2,5)$ evet cevabı verdiği görülmüştür.

Araştırma kapsamında katılımcıların, 'Sağlık ve tıp konularıla ilgili bilgi düzeyinizi nasıl değerlendirirsiniz?' sorusuna ilişkin verdikleri yanıtlar ile nerede yaşadıkları arasında anlamlı ilişki olduğu görülmektedir $\left(X^{2}=15,948 ; p=0,000<0.05\right)$. Bu çerçevede Esenyurt ve Beşiktaş ilçesindeki katılımcıların 'bilgili' yanıtının yakın olduğu saptanmıştır. Diğer yandan Esenyurttaki katılımcıların 18'inin (\%9,0) 'az bilgili', 10'unun $(\% 5,0)$ ise 'çok bilgili' yanıtını verdikleri ortaya çıkmıştır. Araştırma kapsamında Beşiktaş ilçesinde katılımcıların 28'inin $(\% 14,0)$ 'çok bilgili' yanıtını verdikleri, 5'inin $(\% 2,5)$ ise 'az bilgili' yanıtını verdikleri bulgulanmıştır.

Katılımcıların 'Covid-19 salgını ile ilgili bilgi düzeyinizi puanlasanız kendinize kaç puan verirsiniz?' sorusuna ilişkin verdikleri yanıtlar ile nerede yaşadıkları arasında anlamlı ilişki olduğu görülmektedir $\left(X^{2}=46,810 ; p=0,000<0.05\right)$. Bu çerçevede Esenyurt'taki katılımcıların 70'inin (\%35,0) Covid-19 hastalığı ile ilgili bilgi düzeylerine ilişkin 1-10 aralığında belirtilen ölçekte 8 oranını belirttikleri bulgulanmıştır. Katılımcıların 37'sinin $(\% 18,5)$ ise 6 oranını tercih ettikleri görülmüştür. Beşiktaş ilçesindeki katılımcıların 102'sinin (\%51,0) 1-10 arasında belirtilen ölçekte 8 oranını belirttikleri 11 'inin $(\% 5,5)$ ise 6 oranını belirttikleri saptanmıştır. 


\begin{tabular}{|c|c|c|c|c|c|c|c|c|}
\hline & \multicolumn{2}{|c|}{ Esenyurt } & \multicolumn{2}{|c|}{ Beşiktaş } & \multicolumn{2}{|c|}{ Toplam } & \multirow[b]{2}{*}{$\mathrm{p}$} \\
\hline & & $\mathbf{n}$ & $\%$ & $\mathbf{n}$ & $\%$ & $\mathbf{n}$ & $\%$ & \\
\hline \multirow{4}{*}{$\begin{array}{l}\text { Covid-19 salgınıyla ilgili düzenli kontrol } \\
\text { için hastaneye sürekli gider misiniz? }\end{array}$} & \begin{tabular}{|l} 
Düzenli gelmem \\
gerektiğine inaniyorum \\
ama gelemiyorum
\end{tabular} & 34 & $\% 17,0$ & 93 & $\% 46,5$ & 127 & $\% 31,8$ & \multirow{4}{*}{$\begin{array}{l}X^{2}=125,143 \\
p=0,000\end{array}$} \\
\hline & $\begin{array}{l}\text { Düzenli gelmeye } \\
\text { çalışıyorum ama } \\
\text { gelemiyorum }\end{array}$ & 7 & $\% 3,5$ & 4 & $\% 2,0$ & 11 & $\% 2,8$ & \\
\hline & Düzenli olarak geliyorum & 3 & $\% 1,5$ & 52 & $\% 26,0$ & 55 & $\% 13,8$ & \\
\hline & \begin{tabular}{|l}
$\begin{array}{l}\text { Covid-19 ile ilgili bir } \\
\text { sorunum olduğunda } \\
\text { giderim }\end{array}$ \\
\end{tabular} & 156 & $\% 78,0$ & 51 & $\% 25,5$ & 207 & $\% 51,7$ & \\
\hline \multirow{2}{*}{$\begin{array}{l}\text { Covid-19 salgınına yönelik kullandığınız } \\
\text { ilaçların işlevlerini biliyor musunuz? }\end{array}$} & Evet & 52 & $\% 26,0$ & 75 & $\% 37,5$ & 127 & $\% 31,8$ & \multirow{2}{*}{$\begin{array}{l}X^{2}=6,103 \\
p=0,009\end{array}$} \\
\hline & Hayır & 148 & $\% 74,0$ & 125 & $\% 62,5$ & 273 & $\% 68,2$ & \\
\hline \multirow{5}{*}{$\begin{array}{l}\text { Doktorunuzdan hastalığınızla ilgili } \\
\text { ayrıntılı bilgi almadığınızda alternatif bilgi } \\
\text { kaynaklarına başvurur musunuz? }\end{array}$} & $\begin{array}{l}\text { Doktordan bilgi almak için } \\
\text { 1srar ederim }\end{array}$ & 106 & $\% 53,0$ & 120 & $\% 60,0$ & 226 & $\% 56,5$ & \multirow{5}{*}{$\begin{array}{l}X^{2}=10,356 \\
p=0,035\end{array}$} \\
\hline & \begin{tabular}{|l} 
Bilgi alamiyorsam başka \\
kaynaklara yönelirim
\end{tabular} & 26 & $\% 13,0$ & 39 & $\% 19,5$ & 65 & $\% 16,2$ & \\
\hline & Bilgi almak için uğraşmam & 5 & $\% 2,5$ & 4 & $\% 2,0$ & 9 & $\% 2,2$ & \\
\hline & $\begin{array}{l}\text { İternetteki sağlık } \\
\text { sitelerine başvurarak bilgi } \\
\text { almaya çalışırım }\end{array}$ & 23 & $\% 11,5$ & 13 & $\% 6,5$ & 36 & $\% 9,0$ & \\
\hline & $\begin{array}{l}\text { Alanla ilgili bir başka bir } \\
\text { doktora başvururum }\end{array}$ & 40 & $\% 20,0$ & 24 & $\% 12,0$ & 64 & $\% 16,0$ & \\
\hline
\end{tabular}

Tablo 6. Katılımcıların Covid-19 İle İlgili Bilgi Edinme Durumu ve Tedaviye Bakışı

Araştırma kapsamında katılımcıların Covid-19 ile ilgili enformasyon edinme durumu ve tedaviye bakışına ilişkin olarak, 'Covid-19 salgınıyla ilgili düzenli kontrol için hastaneye sürekli gider misiniz?' sorusuna ilişkin verdikleri yanıtlar ile nerede yaşadıkları arasında anlamlı ilişski olduğu görülmektedir $\left(X^{2}=125,143 ; p=0,000<0.05\right)$. Esenyurt ilçesinde katılımcıların 156'sının (\%78,0) 'Covid-19 ile ilgili bir sorunum olduğunda giderim' yanıtını verdikleri saptanmıştır. Katılımcıların 34'ünün $(\% 17,0)$ 'inanıyorum ama gelemiyorum' yanıtını verdikleri ortaya çıkmıştır. Öte yandan Esenyurt ilçesindeki katılımcıların 3'ünün $(\% 1,5)$ 'düzenli geliyorum' yanıtını verdikleri de bulgulanmıştır. Araştırma kapsamında Beşiktaş ilçesinde katılımcıların 93'ünün $(\% 46,5)$ 'inanıyorum ama gelemiyorum', 52'sinin $(\% 26,0)$ ise 'düzenli geliyorum' yanıtını verdikleri görülmüştür. Katılımcıların 51'inin (\%25,5) 'Covid-19’la ilgili bir sorunum olduğunda giderim' yanıtını verdikleri de bulgulanmıştır.

Araştırma kapsamında katılımcıların 'Covid-19 salgınına yönelik kullandığınız ilaçların işlevlerini biliyor musunuz?' sorusuna ilişkin verdikleri yanıtlar ile nerede yaşadıkları arasında anlamlı ilişki olduğu görülmektedir $\left(X^{2}=6,103 ; p=0,009<0.05\right)$. Bu çerçevede Esenyurt ilçesindeki katılımcıların büyük kısmının 148'i $(\% 74,0)$ hayır yanıtını verdikleri görülmüştür. Katılımcıların 52'sinin $(\% 26,0)$ ise evet yanıtını verdikleri saptanmıştır. Araştırma 
çerçevesinde Beşiktaş ilçesinde katılımcıların 125'inin $(\% 62,5)$ hayır yanıtını verdikleri saptanırken, 75 'inin $(\% 37,5)$ evet yanıtını verdikleri bulgulanmıştır.

Katılımcıların 'Doktorunuzdan hastalı̆̆ınızla ilgili ayrıntılı bilgi almadı̆̆ınızda alternatif bilgi kaynaklarına başvurur musunuz?' sorusuna ilişkin verdikleri yanıtlar ile nerede yaşadıkları arasında anlamlı ilişki olduğu görülmektedir $\left(X^{2}=10,356 ; p=0,035<0.05\right)$. Araştırma kapsamında Esenyurt ve Beşiktaş ilçesindeki katılımcıların 'doktordan bilgi almak için ısrar ederim' yanıtlarının oranı yakın olduğu bulgulanmıştır. Katılımcılardan 40'ının ise $(\% 20,0)$ 'alanla ilgili bir başka bir doktora başvururum' yanıtını verdikleri ortaya çıkmıştır. Diğer yandan katılımcıların 23'ünün $(\% 11,5)$ 'internetteki sağllk sitelerine başvurarak bilgi almaya çalışırım' yanıtını verdikleri de ortaya çıkmıştır. Araştırma çerçevesinde Beşiktaş ilçesinde katılımcıların 24'ünün $(\% 12,0)$ 'alanla ilgili bir başka bir doktora başvururum' yanıtını verdikleri, 13'ünün $(\% 6,5)$ ise 'internetteki sağlık sitelerine başvurarak bilgi almaya çalışırım' yanıtını verdikleri bulgulanmıştır.

\begin{tabular}{|c|c|c|c|c|c|c|c|c|}
\hline & & \multicolumn{2}{|c|}{ Esenyurt } & \multicolumn{2}{|c|}{ Beşiktaş } & \multicolumn{2}{|c|}{ Toplam } & \multirow[b]{2}{*}{$\mathbf{p}$} \\
\hline & & $\mathbf{n}$ & $\%$ & $\mathbf{n}$ & $\%$ & $\mathbf{n}$ & $\%$ & \\
\hline \multirow{2}{*}{$\begin{array}{l}\text { Nefesinizi öksürmeden veya rahatsızlık hissetmeden } 10 \\
\text { saniyeden fazla tutabiliyor olmanız koronavirüs (COVID-19) } \\
\text { veya başka herhangi bir akciğer hastalığınızın olmadığı anlamına } \\
\text { gelmez }\end{array}$} & Doğru & 81 & $\% 40,5$ & 112 & $\% 56,0$ & 193 & $\% 48,2$ & \multirow{2}{*}{$\begin{array}{l}X^{2}=9,622 \\
p=0,001\end{array}$} \\
\hline & Yanlış & 119 & $\% 59,5$ & 88 & $\% 44,0$ & 207 & $\% 51,7$ & \\
\hline \multirow{2}{*}{ Soğuk hava ve kar yeni koronavirüsü öldürmez } & Doğru & 123 & $\% 61,5$ & 144 & $\% 72,0$ & 267 & $\% 66,8$ & \multirow{2}{*}{$\begin{array}{l}X^{2}=4,967 \\
p=0,017\end{array}$} \\
\hline & Yanlış & 77 & $\% 38,5$ & 56 & $\% 28,0$ & 133 & $\% 33,2$ & \\
\hline \multirow{2}{*}{ Yeni koronavirüs sivrisinek 1sırığı yoluyla bulaşmaz } & Doğru & 128 & $\% 64,0$ & 145 & $\% 72,5$ & 273 & $\% 68,2$ & \multirow{2}{*}{$\begin{array}{l}\mathrm{X}^{2}=3,334 \\
\mathrm{p}=0,043\end{array}$} \\
\hline & Yanlış & 72 & $\% 36,0$ & 55 & $\% 27,5$ & 127 & $\% 31,8$ & \\
\hline \multirow{2}{*}{$\begin{array}{l}\text { El kurutma makineleri yeni koronavirüsü öldürmede etkili } \\
\text { değildir }\end{array}$} & Doğru & 103 & $\% 51,5$ & 71 & $\% 35,5$ & 174 & $\% 43,5$ & \multirow{2}{*}{$\begin{array}{l}X^{2}=10,416 \\
p=0,001\end{array}$} \\
\hline & Yanlış & 97 & $\% 48,5$ & 129 & $\% 64,5$ & 226 & $\% 56,5$ & \\
\hline \multirow[b]{2}{*}{ Ultraviyole lamba yeni koronavirüsü öldüremez } & Doğru & 72 & $\% 36,0$ & 48 & $\% 24,0$ & 120 & $\% 30,0$ & \multirow{2}{*}{$\begin{array}{l}X^{2}=6,857 \\
p=0,006\end{array}$} \\
\hline & Yanlış & 128 & $\% 64,0$ & 152 & $\% 76,0$ & 280 & $\% 70,0$ & \\
\hline
\end{tabular}

Tablo 7. Katılımcıların Koronavirüs ile İlgili Bilgi Düzeylerin

Araştırma kapsamında katılımcıların 'nefesinizi öksürmeden veya rahatsızlı hissetmeden 10 saniyeden fazla tutabiliyor olmanız koronavirüs (covid-19) veya başka herhangi bir akciğer hastalı̆̆ınızın olmadığı anlamına gelmez' önermesine ilişkin verdikleri yanıtlar ile nerede yaşadıkları arasında anlamlı ilişki olduğu görülmektedir $\left(X^{2}=9,622 ; p=0,001<0.05\right)$. Bu çerçevede Esenyurt ilçesinde katılımcıların 81'inin (\%40,5) ise doğru yanıtını verdiği görülürken Beşiktaş ilçesinde ise katılımcıların 112'sinin $(\% 56,0)$ doğru yanıtını verdikleri saptanmıştır. 
Katılımciların soru formunda bulunan 'soğuk hava ve kar yeni koronavirüsü öldürmez' önermesine ilişkin verdikleri yanıtlar ile nerede yaşadıkları arasında anlamlı ilişki görülmektedir $\left(X^{2}=4,967 ; p=0,017<0.05\right)$. Esenyurt ilçesinde katılımcıların 123'ünün $(\% 61,5)$ doğru yanıtını verdikleri görülürken Beşiktaş ilçesinde ise katılımcıların 144'ünün $(\% 72,0)$ doğru cevaba yöneldikleri bulgulanmıştır.

Araştırma kapsamında katılımcılara yöneltilen 'yeni koronavirüs sivrisinek ısırı̆̆g yoluyla bulaşmaz' önermesine verdikleri yanıtlar ile nerede yaşadıkları arasında anlamlı ilişki olduğu görülmektedir $\left(X^{2}=3,334 ; p=0,043<0.05\right)$. Bu çerçevede Esenyurt ilçesinde katılımcıların 128'inin $(\% 64,0)$ doğru yanıtını verdikleri saptanırken Beşiktaş ilçesinde katılımcıların 145 'inin ise $(\% 72,5)$ doğru yanıtı verdikleri görülmüştür.

Katılımcıların 'el kurutma makineleri yeni koronavirüsü öldürmede etkilidir değildir' önermesine ilişkin verdikleri yanıtlar ile nerede yaşadıkları arasında anlamlı ilişki olduğu görülmektedir $\left(X^{2}=10,416 ; p=0,001<0.05\right)$. Bu çerçevede Esenyurt ilçesinde katılımcıların 103 'ünün $(\% 51,5)$ doğru yanıtını verdikleri görülürken Beşiktaş ilçesinde katılımcıların sadece 71 'inin $(\% 35,5)$ doğru yanıtını verdikleri ortaya çıkmıştır.

Araştırma kapsamında katılımcıların 'ultraviyole lamba yeni koronavirüsü öldürmez' önermesine ilişkin verdikleri yanıtlar ile nerede yaşadıkları arasında anlamlı ilişki olduğu görülmektedir $\left(X^{2}=6,857 ; p=0,006<0.05\right)$. Esenyurt ilçesinde katılımcıların 72 'sinin $(\% 36,0)$ doğru yanıtını verdikleri bulgulanırken Beşiktaş ilçesinde katılımcıların 48'inin $(\% 24,0)$ ise doğru yanıtını cevabı verdikleri saptanmıştır.

\section{Sonuç}

Bireylerin sahip olduğu eğitim, ekonomi, meslek, sağlık hizmetleri, barınma imkânları gibi sınıfsal unsurlar farklı sosyal katmanların oluşmasına neden olmaktadır. $\mathrm{Bu}$ durum sahip olduğu sınıfsal konumlara göre bireylerin toplumsal farkındalığını, bilgi düzeylerini, enformasyona yönelimini ve anlamlandırmasını etkilemektedir. Böylelikle SES'i yüksek olan sınıfsal yapıların alt statüdekilere göre daha fazla bilgiye sahip olduğu saptanmıştır. $\mathrm{Bu}$ yüzden toplumun farklı sınıfsal yapıları arasında bilgi açığı ortaya çıkmıştır. Bu durumun oluşmasında demografik özellikler, teknoloji ve sağlık hizmetleri gibi unsurlar etkili olmaktadır. Bu anlamda araştırma kapsamında incelenen Esenyurt ilçesindeki katılımcıların büyük çoğunluğunun ilkokul eğitim düzeyine sahip olduğu görülürken Beşiktaş ilçesindeki katılımcılarda ise lise ve üniversite eğitim düzeyinin yoğunlukta olduğu bulgulanmaştır. 
Ayrıca bireylerin bilgi açığını etkileyen bir diğer demografik özellik olan meslek yapıları ve gelir düzeyleri de araştırma kapsamında incelenen ilçelerde farklılık göstermektedir. $\mathrm{Bu}$ bağlamda Esenyurt ilçesindeki katılımcıların çoğunluğunun 3000 TL'den az gelir düzeyine sahip olduğu saptanırken Beşiktaş'taki katılımcıların yüzde 60'dan fazlasının ise 3000 TL'nin üstünde gelir elde ettiği ortaya çıkmıştır. Bireylerin gelir düzeylerinde etkili olan unsurlar arasında yer alan meslek yapılarına bakıldığında ise Esenyurt ve Beşiktaş ilçesindeki katılımcıların büyük çoğunluğunun araştırma kapsamında olmayan diğer meslek gruplarında çalıştıkları görülmektedir. Ancak katılımcıların memur olma durumlarının Beşiktaş’ta Esenyurt ilçesine göre 3 kat daha fazla olduğu saptanmıştır. Ayrıca işçi kategorisindeki yoğunluğun Esenyurt'ta Beşiktaş ilçesine göre neredeyse iki katına yakın olduğu ortaya çıkmıştır. Bu durum sadece toplum içerisindeki sınıfsal farklılıklardan yola çıkarak oluşan sosyo-demografik özellikleri etkilememektedir. Ayrıca teknolojik yapıların kullanımına da etki ederek bir eşitsizliği doğurmaktadır. Böylelikle araştırma kapsamında incelenen ilçelerdeki katılımcılarda görülen sınıfsal sosyo-demografik farklılıklar bireylerin teknoloji kullanım yeterliliğini farklılaştırarak, bu araçlardan gelen enformasyonu anlamlandırma noktasında da eşitsizliklere neden olarak bilgi açığını oluşturmaktadır.

Teknolojik eşitsizliklerin üretildiği alanlardan biri olan akıllı telefonun kullanımı noktasında Esenyurt ilçesindeki katılımcıların Beşiktaş ilçesine oranla daha fazla başlangıç aşamasında olduğu saptanmıştır. Bu durum katılımcıların akıllı telefonu kullanma süresini ve ne kadar sıklıkla kullandığına yönelik olan ilişkilerini etkilemektedir. Böylelikle araştırma kapsamında Beşiktaş ilçesindeki katılımcıların yarısının akıllı telefonu kullanma durumları 10 yıl ve üzerinde olurken Esenyurt ilçesindeki katılımcıların çoğunluğunun ise 7 yıl ve üzerinde bir telefon kullanım süresine sahip olduğu ortaya çıkmıştır. Bu bağlamda akıllı telefonu kullanma sıklığına bakıldığında ise Beşiktaş ilçesindeki katılımcıların Esenyurttakilere göre daha sık akıllı telefonu kullandığı görülmüştür. Ayrıca araştırma kapsamında incelenen ilçelerdeki akıllı telefona yönelik ortaya çıkan eşitsizlik katılımcıların bu teknolojik aygıta yönelik kendilerini geliştirme ihtiyaçlarını da farklılaştırmaktadır. Bu yüzden Esenyurt ilçesindeki katılımcılar hem demografik özelliklerinden hem de akıllı telefon kullanım yetersizliğinden dolayı Beşiktaş ilçesindekileri göre kendilerini daha fazla geliştirme ihtiyacı duymaktadırlar.

Akıllı telefonun kullanımı noktasında ilçelerdeki farklılığın temelinde katılımcıların sahip olduğu tutumlarda etkili olmaktadır. Bu bağlamda Beşiktaş ilçesindeki katılımcıların tamamına yakını akıllı telefon kullanımına karşı olmadığı görülmüştür. Ancak sınıfsal düzlemde yaratılan eşitsizlik katılımcıların akıllı telefona yönelik kullanma pratiklerini de 
etkilemektedir. $\mathrm{Bu}$ yüzden Beşiktaş ilçesindeki katılımcıların yarısına yakınının teknolojik okuryazarlığa karşı bir bilinç sahibi olması nedeniyle akıllı telefon kullanmadan da zaman geçirebileceği görülmektedir. Bu durum sosyo demografik düzeyi yüksek olan sosyal sınıfların teknoloji aracılığıyla bilgilendirilmesini etkilemektedir. Böylelikle toplumun yüksek SES'ine sahip kesimleri teknoloji dışındaki bilgi araçlarını da kullanarak bilgi alabilmektedir. Ancak Esenyurt ilçesindeki katılımcıların yarısından fazlası ise teknolojik bir determinizm içerisine girerek akıllı telefonla daha çok zaman geçirip ihtiyaçlarını akıllı telefon olmaksızın karşılayamayacakları görülmektedir. Bu durum düşük SES'e sahip sosyal sınıfların teknolojik aygıtlar dışındaki bilgi araçlarına çok yönelmediğini ortaya çıkarmıştır. Böylelikle tıpkı sosyo demografik özelliklerden kaynaklanan bilgi açıklığı özelde akıllı telefon kullanımı genelde ise teknoloji kullanımından kaynaklı olarak bir bilgi açığını ortaya çıkarmıştır.

Toplumdaki sosyal sınıflar arasında yaşanan bilgi açıklığı sadece iletişim teknolojileri veya akıllı cep telefonlarıyla sinırlı olmamaktadır. Ayrıca bireylerin belirli konularda bilgilendirilmesini sağlayan aplikasyonlar özelinde de devam etmektedir. $\mathrm{Bu}$ bağlamda Covid-19 salgını sürecinde de bireyler sağlık konularındaki bilgi düzeylerini arttırabilmek amacıyla HES uygulamasına yönelmektedir. Ancak bu yönelim bireylerin demografik özellikleri ve teknoloji kullanım düzeylerine göre farklılaşmaktadır. Bu bağlamda Esenyurt ilçesindeki katılımcıların yarısına yakını HES uygulamasını tesadüfen öğrendiğini belirtirken Beşiktaş’taki katılımcıların yarısından fazlası ise HES uygulamasından çeşitli konularda bilgi almak için sık sık kullandığını söylemektedir. Ayrıca Beşiktaş ilçesindeki katılımcılar HES uygulaması aracığıyla bilgilenmenin yanı sıra doktorlardan da bilgi almanın gerekliliğini ifade etmişlerdir. Ancak Esenyurttaki katılımcılar ise sadece HES uygulamasına bağlı kalarak salgına yönelik bilgilenmeye çalışmışlardır. Bu durum bilinçli bir özne tarafından elde edilen bilginin sosyal sınıflara göre bireylerin bilgi düzeylerini etkilemektedir. Bu yüzden Beşiktaş ilçesindeki bireylerin Esenyurt ilçesindekilere göre hem teknolojiyi hem de bilgiye erişim yollarını daha etkili ve faydalı kullanmaktadır. Ayrıca yüksek SES'e sahip olan Beşiktaş’taki bireylerin sadece iletişim teknolojilerindeki bilgilere bağlı kalmadığını ve farklı bilgi mecralarına da yöneldiği göstermektedir. Buna karşın Esenyurt'taki bireyler ise salgına yönelik bilgi düzeylerini sadece HES uygulaması üzerinden elde etmektedir. Bu durum sosyal sınıflar arasındaki bilgi açığının artmasına neden olmaktadır. Çünkü bilgi açığı modeli toplumun temelindeki sosyal yapının bir sonucu olan bilgi akışının homojen olmadığını savunmaktadır. Böylelikle toplumun farklı katmanlarında oluşan heterojen bilgi akışı farklı enformasyon gediklerine neden olmaktadır (Bonfadelli, 2002: 67). 
Sağlıkta yaşanan sosyal eşitsizlik toplumda sağlıkla ilgili konularda bilgi açığı yaratmaktadır. $\mathrm{Bu}$ açığın büyümesinde kişilerin eğitim ve gelir düzeylerinin yanında medya takibi ya da konuyla ilgili motivasyonları, bilimsel anlamda sağlıkla ilgili haberlere verilen önemin az olması gibi unsurlar önemli bir etkendir (Ettema vd., 1983: 517). Ayrıca medyaya ve mesajlara dikkat ve bilgilerin hatırlanması ve saklanması, daha düşük SES gruplarına kıyasla daha yüksek SES grupları tarafından daha iyi anlaşılmaktadır (Nielsen-Bohlman ve ark., 2004: 7). Bu durumu destekler nitelikte araştırmada katılımcıların sağlık ve tıp konularıyla ilgili bilgili olma düzeylerinin Beşiktaş ilçesindeki oranı, Esenyurt ilçesindekinin 3 katı olmaktadır. Araştırma özelinde bakıldığında ise katılımcıların Covid-19 hastalığı ile ilgili bilgi düzeylerine göre Beşiktaş ilçesindeki katılımcıların tamamına yakınının bilgi düzeyinin yüksek olduğu görülürken, Esenyurtta ise sadece her 4 katılımcıdan 3 'nün bilgi düzeyinin yüksek olduğu saptanmıştır. Covid-19 hastalığına yönelik katılımcıların bilgi düzeylerini spesifikleştirerek ölçmek için doğruluğu Dünya Sağlık Örgütü tarafından kanıtlanmış 8 ifadeden yola çıkarak katılımcıların Koronovirüs salgınına yönelik bilgi düzeyi ölçülmüştür. $\mathrm{Bu}$ bağlamda Beşiktaş ilçesindeki katılımcıların bu ifadelerden 6 tanesinde, Esenyurt ilçesindeki katılımcılara oranla daha yüksek oranda doğru cevap verdiği görülürken sadece 2 tanesinde Esenyurt ilçesindeki katılımcıların daha yüksek oranda doğru cevap verdiği saptanmıştır.

Katılımcıların ortaya çıkan Covid-19 salgınına yönelik bilgi düzeylerinin oluşmasında internet ve doktorların en çok kullanılan bilgi kaynakları oldukları görülmüştür. Bu durum araştırma kapsamında incelenen ilçedekileri bireylerin Covid-19 salgınıyla ilgili bilgiye erişim düzeylerini de farklılaştırmaktadır. Bu bağlamda Esenyurt ilçesindeki bireyler Covid-19 salgınıyla ilgili bilgi elde edebilmek için internetteki sağlık sitelerine yönelirken Beşiktaştakiler ise daha çok doktorları bir kaynak olarak kullanmaktadır. Bu yüzden Beşiktaş ilçesindeki bireylerin Covid -19 salgınıyla ilgili düzenli olarak hastaneye gitme durumları Esenyurttakilere göre neredeyse 17 kat daha fazla olmaktadır. Bunun bir sonucu olarak da Beşiktaş'daki katılımcıların 3'te 1'i Covid 19 salgınıyla ilgili ilaçların işlevlerini bilirken Esenyurtta ise bu durum 4 'te 1 oranın da kalmaktadır. Ortaya çıkan bu ilişkiler bireylerin bilgi edinirken hangi kaynakları kullandığı bu bilgileri nasıl edindiği, ne oranda doğru anladığı ve toplumsal hayatta nasıl kullandığı önem kazanmaktadır. Bu durum bireylerin SES'lerine göre değişmektedir. Böylece toplumsal yaşamda sağlık ve teknoloji konularında bir bilgi açığ ortaya çıkmakta ve bu bilgi açığı toplumsal bir eşitsizliği meydana getirmektedir. Çalışma kapsamında bu eşitsizlik kişilerin Covid 19 salgınına yakalanma durumunda kendini 
göstermektedir. Toplumun görece daha üst sosyal sınıfında olan daha iyi eğitim görmüş ve bunun bir sonucu olan medya ve teknolojiyi daha bilinçli kullanan Beşiktaş ilçesindeki katılımcıların Esenyurt ilçesindeki katılımcılara göre Covid 19 salgınını geçirme durumunun 3 kat daha az olduğu görülmüştür.

\section{Kaynakça}

Afacan, Ersin ve Avcı, Nazmi (2020), “Koronavirüs (Covid-19) Örneği Üzerinden Salgın Hastalıklara Sosyolojik Bir Bakış”, Avrasya Sosyal ve Ekonomi Araştırmaları Dergisi, 7(5), s. 1-14.

Ahmad1, Ramazan (2020), “Koronavirüs Pandemisinin (Kovid-19) Toplumsal Etkileri”, Bilim Armonisi, 3(2), s. 65-72.

Akat, Muhammet ve Karataş, Kasım (2020), "Psychological Effects of COVID-19 Pandemic on Society and Its Reflections on Education", Electronic Turkish Studies, 15(4), p. $1-13$.

Aktan, Can Coşkun ve Tunç, Mehtap (1998), "Bilgi Toplumu ve Türkiye”, Yeni Türkiye Dergisi, Ocak- Şubat, s.118-134.

Angermayer, Mathias ve Klusmann, Dietrich. (1987). From Social Class to Social Stress: New Developments in Psychiatric Epidemiology. From Social Claas to Social Stress inside Editor Matias Angermeyer, Springer: Berlin. p. 2-15.

Aydın, Mustafa (2010), Bilgi Sosyolojisi, Açılım Kitap, İstanbul

Aydoğan, Filiz ve Kırık, Ali Murat (2012), “Alternatif Medya Olarak Yeni Medya”, Akdeniz Üniversitesi İletişim Fakültesi Dergisi, 18, s.58-69.

Ayhan, Bünyamin (2018), İletişim Sosyolojisi, LiteraTürk, Konya

Aziz, Aysel (1982), Toplumsallaşma ve Kitlesel İletişim, Ankara Üniversitesi Basın-Yayın Yüksek Okulu Yayınları, Ankara.

Becker, Stefan., Miron-Shatz, Talya., Schumacher, Nikolaus. Krocza, Johann., Diamantidis, Clarissa., Ve Albrecht, Urs-Vito. (2014), mHealth 2.0: Experiences, Possibilities, and Perspectives. JMIR mHealth uHealt, 2(2), p. 1-12.

Beneton, Philippe (1991), Toplumsal Sınıflar, Hüsnü Dilli (çev), İletişim Yayınları, İstanbul.

Bonfadelli, Heinz (2002). "The Internet and Knowledge Gaps: A Theoretical and Empirical Investigation", European Journal of Communication, 17(1), p.65-84. 
Booth, Douglas. E (2020). "Post-materialism's Social Class Divide: Experiences and Life Satisfaction", Journal of Human Values, p.1-20.

Bottero, Wendy (2005), Stratification, Routledge, London.

Bozkurt, Aras (2020), "Koronavirüs (Covid-19) Pandemi Süreci ve Pandemi Sonrası Dünyada Eğitime Yönelik Değerlendirmeler: Yeni Normal ve Yeni Eğitim Paradigması”, Açıköğretim Uygulamaları ve Araştırmaları Dergisi, 6(3), s.112-142.

Bozkurt, Nejat (2004), Bilimler Tarihi ve Felsefesi, Morpa Kültür Yayınları, İstanbul

Bozkurt, Yasemin, Zeybek, Zekiye ve Aşkın, Rüstem (2020), "Covid-19 Pandemisi: Psikolojik Etkileri ve Terapötik Müdahaleler”, İstanbul Ticaret Üniversitesi Sosyal Bilimler Dergisi, 19(37), s.304-318.

Bumpus, John, Umeh, Zimife ve Harrıs, Angel (2019), "Social Class and Educational Attainment: Do Blacks Benefit Less from Increases in Parents' Social Class Status?”, Sociology of Race and Ethnicity, 6, p.223-241.

Cohen, Dov, Shın, Faith, Liu, Xi, Ondısh, Peter ve Kraus, Michael (2017), "Defining Social Class Across Time and Between Groups", Personality and Social Psychology Bulletin, 43(11), p.1530-1545.

Cohen, Stewart (1986), "Knowledge And Context”, The Journal Of Philosophy, 83, 10, P.574-583.

Compton, Michael ve Shim, Ruth (2015), The Social Determinants of Mental Health. American Pyschiatric Publishing, Washington.

Çelik, Ramazan (2019), "Bilgi Gediği Hipotezinde Tekno İyimserlik ve Tekno Kötümserlik”, Sosyal Bilimler Araştırma Dergisi, 8(2), s. 64-76.

Çoştu, Yakup (2009), “Toplumsallaşma Kavramı Üzerine Sosyolojik Bir Değerlendirme”, Dinbilimleri Akademik Araştırma Dergisi, 9(3), s.117-140.

Day, Katy, Rickett, Bridgette ve Woolhouse, Maxine (2020), Critical Social Psychology of Social Class, Palgrave Macmillan, Switzerland.

Diemer, Matthew, Misty, Rashmita, Wadsworth, Martha, Lopez, Irene Ve Reımers, Faye. (2013), "Best Practices in Conceptualizing and Measuring Social Class in Psychological Research", Analyses of Social Issues and Public Policy, 13(1), p.77-113. 
Dijk, Van, Jan (2018). Ağ Toplumu, Özlem Sakin (çev), Epsilon Yayınevi, İstanbul.

Donohue, George Tichenor, Phillip ve Olien. Clarice (1975), "Mass Media and The Knowledge Gap: A Hypothesis Reconsidered”, Communication Research, 2, 1, p. $3-23$.

Ettema, James ve Kline, Gerald (1977), "Deficits, Differences, and Ceilings: Contingent Conditions for Understanding the Knowledge Gap", Communication Research, 4,2, p.179-202.

Ettema, James, Brown, Joshua ve Luepker, Russell (1983), “Knowledge Gap Effects İn a Health İnformation Campaign”, Public Opinion Quarterly, 47, p.516-527.

Foucault, Michel (2011), Bilginin Arkeolojisi, Ayrıntı Yayınları, İstanbul.

Garnsey, Peter ve Saller, Richard (2014), The Roman Empire. Bloomsbury. London.

Genova, Bissy ve Greenberg, Bradley (1972), Interests in News and the Knowledge Gap, Public Opinion Quarterly, 43, (1), pp.79-91.

Geray, Haluk ve Aydoğan, Aylin (2010), Yeni İletişim Teknolojileri ve Etik, (Editörler), Bülent Çaplı Ve Hakan Tuncel. Televizyon Haberciliğinde Etik, Ankara: Fersa Matbaacilik, s.305-321.

Giddens, Anthony (2012), Sosyoloji, Kırmızı Kedi Yayınları, İstanbul.

Gonzalez, Llúcia, Cortés-Sancho, Rosa, Murcia, Mario. Ballester, Ferran, Rebagliato, Marisa Ve Rodríguez-Bernal, Clara Liliana (2020), “The Role of Parental Social Class, Education and Unemployment on Child Cognitive Development”, Gac Sanit, 34(1), p.51-60.

Grusky, David (2008), Social Stratification, Westview Press, USA.

Güz, Nurettin (2005), Haberde Yönlendirme ve Kamuoyu Araştırmaları, Nobel Basımevi, İstanbul.

Habermas, Jurgen (1997), Bilgi ve İnsansal İlgiler, Küresel Yayınları, İstanbul.

Holbrook, Thomas (2002), "Presidential Campaigns and the Knowledge Gap", Political Communication, 19, p.437-454.

Illıch, Ivan (2006), Okulsuz Toplum, Celal Üner (çev), İstanbul: Oda Yayınları.

Karataş, Zeki (2020), “COVID-19 Pandemisinin Toplumsal Etkileri, Değişim ve Güçlenme”, Türkiye Sosyal Hizmet Araştırmaları Dergisi, 4(1), s. 3-17. 
Katzman, Natan (1974), “The Impact of Communication Technology: Promises and Prospects", Journal of Communication, 24(4), p.47-58.

Key, Valdimer, Orlando (1961), Public Opinion and American Democracy, New York: Knopf.

Kırmızıül, Hafize, Gamze (2020), “Covid-19 Salgını ve Beraberinde Getirdiği Eğitim Süreci”, Avrasya Sosyal ve Ekonomi Araştırmaları Dergisi, 7(5), s.283-289.

Lahelma, Eero Lallukka, Tea Laaksonen, Mikko Martıkaınen, Pekka Rahkonen, Ossi Chandola, Tarani Head, Jenny Marmot, Michael Kagamımorı, Sadanobu Tatsuse, Takashi Sekine, Michikazu (2010), "Social Class Differences In Health Behaviours Among Employees From Britain, Finland and Japan: The Influence of Psychosocial Factors", Health and Place, 16, p.61-70.

Lahtinen, Hannu, Mattila, Mikko, Wass, Hanna ve Martıkainen, Pekka (2017), "Explaining Social Class Inequality in Voter Turnout: The Contribution of Income and Health", Scandinavian Political Studies, 40(4) p.388-410.

Lahtinen, Hannu, Sirniö, Outi ve Martıkainen, Pekka (2018), "Social Class and the Risk Of Unemployment: Trends, Gender Differences And The Contribution Of Education", Acta Sociologica, 63(3) p.303-321.

L1, Shukai., Zhang, Qianyun ve Muenning, Peter (2018), "Subjective assessments of income and social class on health and survival: An Enigma", Population Health, 6, p.295-300.

Marmot, Michael (2004), Status Syndrome, Bloomsbury, London.

Mc Quail, Denis ve Windahl, Sven (2010), İletişim Modelleri Kitle İletişim Çalışmalarında Konca Yumlu, (çev), İmge Kitabevi, İstanbul.

Mutlu, Erol (2012), İletişim Sözlüğü, Sofos Yayınları, Ankara.

Nielsen-Bohlman, Lynn, Panzer, Allison, ve Kındıg, David (2004), Health Literacy. National Academies Press, Washington.

Özkan, Hüseyin, Hasan (2006), “Popüler Kültür ve Eğitim”, Kastamonu Eğitim Dergisi, 14(1), s.29-38.

Pope, Witney (2008), Emile Durkheim, Sosyolojik Düşüncede İz Bırakanlar, Editör Rob Stones İstanbul: Bağlam Yayıncılık. 
Reay, Diana (2006), “The Zombie Stalking English Schools: Social Class and Educational Inequality", British Journal of Educational Studies, 54(3), p.288-307.

Reay, Diana (2010), Sociology, Social Class And Education, (Eds), Michael W. Apple, Stephen J. Ball and Luis Armando Gandin. The Routledge International Handbook of the Sociology of Education, Routledge:London, p.396-405.

Ritzer, George (2011), Modern Sosyoloji Kuramları, Himmet Hülür (çev), De Ki Yayıncılık, Ankara,

Russell, Bertrand (1999), Egitim Üzerine, Nail Bezel (çev), Say Yayınları, İstanbul.

Samadova, Vafa (2021), "Bilgi Toplumu”, Ayrıntı Dergisi, 8, 94, s.69-73.

Saunders, Peter (2001), Social Class and Stratification. Routledge:London.

Selamzade, Fuad, Korkmazer, Fuat, Bostan, S ve Yusifbeyli, Gülnar (2020), “Covid-19 Pandemisinin Toplum Üzerine Etkisi: Azerbaycan Örneği”, Türkiye Klinikleri J Health Sci, 5, (2), s.278-87.

Severın, Joseph, Werner ve Tankard, William, James (2014), Communication Theories Origins, Methods and Uses in Mass Media, Pearson Education Limited, Edinburgh.

Sorensen, Kristine, Karuranga, Suvi, Denysıuk, Eva ve Mclernon, Laryn (2018), "Health Literacy and Social Change: Exploring Networks And Interests Groups Shaping The Rising Global Health Literacy Movement”, Global Health Promotion, 25(4), p. 89-92.

Sperght, Kimberly (1999), "Gaps In The Worldwide İnformation Explosion: How The Internet Is Affecting The Worldwide Knowledge Gap", Telematics And Informatics, 16, p.135-150.

Star, Shirley ve Hughes, Helen, Macgill (1950), "Report of an Educational Campaign: The Cincinnati Plan for the United Nations", American Journal of Sociology, 55, p.389-397.

Statista.com (2020), “Growth In The Number Of Medical Apps Downloaded During The COVID-19 Pandemic By Country In 2020”, https://www.statista.com/statistics/1181413/ Erişim Tarihi: 10.02.2021.

Stephens, Nicole, Brannon, Tiffany, Markus, Hazel, Rose ve Nelson, Jessica (2015) "Feeling at Home In College: Fortifying School-Relevant Selves to Reduce Social Class Disparities In Higher Education”, Social Issues and Policy Review, 9(1), p.1-24. 
Stormacq, Coraline, Van Den Broucke, Stephan Ve Wosınsk1, Jacqualine (2018),"Does Health Literacy Mediate the Relationship Between Socioeconomic Status and Health Disparities? Integrative Review”, Health Promotion International, 34(5) p.1-17.

Şeker Bektaş, Tülay (2004), Yeni Bir İletişim Teknolojisi Olarak İnternet ve Bilgi Açığı, Doktora Tezi, Selçuk Üniversitesi Sosyal Bilimler Enstitüsü, Konya.

Şeker Bektaş, Tülay (2005), İnternet ve Bilgi Açı̆̆ı, Çizgi Kitabevi, Konya.

Terkan, Banu (2005), Gündem Belirleme Medya ve Siyasal Gündem Üzerine Bir Çalışma, Tablet Kitabevi, , Konya.

Tezcan, Mehmet (1985), Eğitim Sosyolojisi, Ankara Üniversitesi Eğitim Bilimleri Fakültesi Yayınları, Ankara.

Tichenor, Philipp, Donohue, George ve Olien, Clarice. (1970), "Mass Media Flow and Differential Growth In Knowledge”, Public Opinion Quarterly, 34, p.159-170.

Toffler, Alvin (2008), Üçüncü Dalga, Koridor Yayıncılık, İstanbul.

Tuik.gov.tr (2021). Okuma Yazma Bilmeyen Sayısı, https://cip.tuik.gov.tr/\#, Erişim Tarihi: 06.06.2021.

Twitter.com/_hayatevesigar, (2021). Hayat $\quad$ Eve https://twitter.com/_hayatevesigar/status/1338044578226724864/photo/1, Erişim Tarihi: 06.06.2021.

Uçak, Nazan (2000), “Bilgi Üzerine Kuramsal Bir Yaklaşım”, Bilgi Dünyası, 1,1, s.143-159.

Uçkun, Seher, Uçkun, Gazi ve Latif, Hasan (2005). Bilgi Toplumu ve Bilgi Yönetimi, (Editörler) Çoşkun Can Aktan ve İstiklal Y. Vural. Bilgi Yönetimi, Konya: Çizgi Kitapevi.

Viswanath, Katam ve Finnegan, John (2006), “The Knowledge Gap Hypothesis: Twenty-Five Years Later" Annals of the International Communication Association, 19, 1, p.187-228.

Wearesocial.com (2021). Digital 2021, https://wearesocial.com/digital-2021 Erişim Tarihi: 06.06.2021.

Weber, Max (2019), Economy and Society, Harvard University Press: London.

Wikipedia.org (2021). COVID-19 apps, https://en.wikipedia.org/wiki/COVID-19_apps, Erişim Tarihi, 06.06.2021. 
www.statista.com. (2021). Adoption Of Government Endorsed COVID-19 Contact Tracing Apps In Selected Countries As Of July 2020, https://www.statista.com/statistics/1134669/share-populations-adopted-covid-contact-t racing-apps-countries/ Erişim Tarihi: 06.06.2021.

Yamamoto, Yoko (2013), “Social Class and Japanese Mothers' Support of Young Children's Education: A Qualitative Study", Journal of Early Childhood Research, 13(2) p.165-180.

Yanık, Hayrullah ve Güz, Nurettin (2017), "Bilgi Açığı Hipotezi ve Yeni Medya”, Gazi Üniversitesi İletişim Fakültesi Dergisi, 5, 2, s.1-14.

Yıldız, Seda ve Karakaş, Derya, Gültekin (2019), “Türkiye'de Eğitim Eşitsizliğinin Farklı Yüzleri”, Anadolu Üniversitesi Sosyal Bilimler Dergisi, 19, 2, s.271-292.

Yu, Siyu ve Blader, Steven (2019). "Why Does Social Class Affect Subjective Well-Being? The Role of Status and Power", Personality and Social Psychology Bulletin, 46(3), p.331-348. 